Review

\title{
A Review on Techno-Economic Assessment of Solar Water Heating Systems in the Middle East
}

\author{
Mehran Dehghan ${ }^{1}$ D, Carlos F. Pfeiffer ${ }^{2}$, Elyas Rakhshani ${ }^{3, *(\mathbb{D})}$ and Reza Bakhshi-Jafarabadi ${ }^{4, *(D)}$ \\ 1 RAHSun Renewable Energy Co., Mashhad 9177948974, Iran; mehran_dehghan2000@yahoo.com \\ 2 Department of Electrical Engineering, Information Technology and Cybernetics, University of South-Eastern \\ Norway, Kjølnes Ring 56, 3918 Porsgrunn, Norway; carlos.pfeiffer@usn.no \\ 3 Department of Electrical Sustainable Energy, Delft University of Technology, Mekelweg 4, \\ 2628 CD Delft, The Netherlands \\ 4 Department of Electrical Engineering, Faculty of Engineering, Ferdowsi University of Mashhad, \\ Mashhad 9177948974, Iran \\ * Correspondence: elyas.rakhshani@gmail.com (E.R.); r.bakhshi@mail.um.ac.ir (R.B.-J.)
}

Citation: Dehghan, M.; Pfeiffer, C.F.; Rakhshani, E.; Bakhshi-Jafarabadi, R. A Review on Techno-Economic Assessment of Solar Water Heating Systems in the Middle East. Energies 2021, 14, 4944. https://doi.org/ $10.3390 /$ en14164944

Academic Editor: Ioan Sarbu

Received: 19 July 2021

Accepted: 10 August 2021

Published: 12 August 2021

Publisher's Note: MDPI stays neutral with regard to jurisdictional claims in published maps and institutional affiliations.

Copyright: (c) 2021 by the authors. Licensee MDPI, Basel, Switzerland. This article is an open access article distributed under the terms and conditions of the Creative Commons Attribution (CC BY) license (https:// creativecommons.org/licenses/by/ $4.0 /)$.

\begin{abstract}
Currently, the economy of Middle Eastern countries relies heavily on fossil fuel sources. The direct and indirect adverse consequences of fossil fuel utilization for power generation enforce the region's countries to raise the share of renewable energy. In this context, various incentive policies have been developed to encourage the residential and industrial sectors to support a portion of energy needs through renewable energy resources. In this case, a solar water heating system (SWHS) as an application of solar thermal technology provides some of the heat energy requirements for domestic hot water (DHW) and space heating, supported conventionally by electricity or natural gas, or even other fossil fuels. This paper reviews the feasibility of the SWHS in the Middle East region from technical and economical standpoints and investigates some of the progress, challenges, and barriers toward this market. The pay-back times and $\mathrm{CO}_{2}$ emission reduction under different incentive frameworks and configurations of each system have been assessed in this context. Furthermore, the advantages and weaknesses of the SWHS in several countries have been reported. Finally, various guidelines have been proposed to enhance the development of this technology.
\end{abstract}

Keywords: solar water heating system; solar thermal system; space heating; domestic hot water; renewable energy

\section{Introduction}

Recently, sustainable, noise-free, and environmentally friendly solar energy has been developed at a steady pace around the world to replace fossil fuel resources. Solar energy has been exploited in several ways, such as producing electricity, thermal usages, water treatment systems, and solar water heating systems (SWHS). The SWHS is known as a common application of solar energy where the received radiation is changed into heat and then transferred into a circulated medium, mostly water and air [1]. By this means, electric water heaters are substituted by SWHS to support space heating and domestic hot water (DHW) [2]. According to the aforementioned advantages and extensive developments in solar water heaters' design within the last 15 years, the global solar water heating market has been raised drastically [3]. For instance, the Indian government has set specific goals to develop SWHS [4], China started research and development projects in the early 1980s to promote this technology [5], Australia maximized the use of SWHS in Sydney Olympic Athletes' Village [6], and SWHS has been widely exploited in Brazil since 1990 [7]. Taiwan has also introduced some subsidies for developing SWHS: 2.27 million $\mathrm{m}^{2}$ solar collectors were installed in the residential areas for supplying DHW and space heating by the end of 2013. Through this, 98,700 tons of oil and 319,000 tons of $\mathrm{CO}_{2}$ emissions have been saved in the country [8]. There have also been some efforts in the use of SWHS in cold areas such 
as Canada [9], in which 35\% of total space heating and hot water demands are supplied by this technology. In a southern European country with an acceptable solar intensity, SWHS can save around 70\% energy [10].

Although the initial cost of SWHS is greater than conventional heaters in most countries, there are some advantages of using this system. For instance, there is an accepted monthly electricity saving in New Zealand using SWHS in comparison with heat pump water, especially during the wintertime (Figure 1) [11]. Thus, it was estimated that more than 130 countries were taking advantage of using SWHS in commercial, industrial, and residential sectors, with either glazed or unglazed solar thermal systems, by the end of 2018 [12].

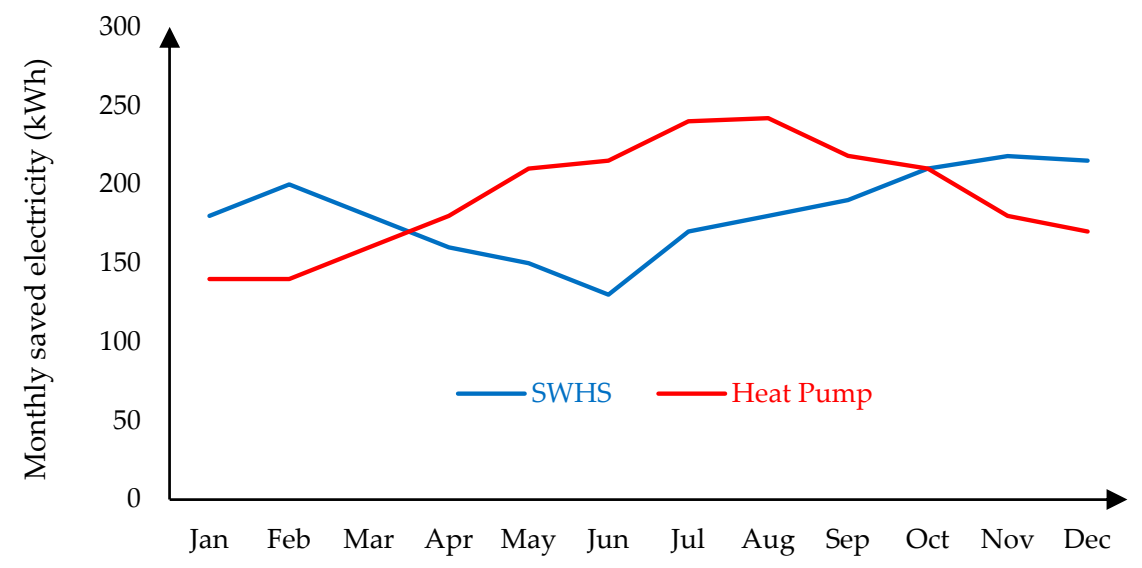

Figure 1. Comparing the monthly saved electricity by using SWHS and heat pump for a medium level user in New Zealand [11].

The Middle East is an Afro-Eurasian region, including 18 countries with a dense and growing population. The region average solar intensity is annually $2000-3200 \mathrm{kWh} / \mathrm{m}^{2}$, implying a high potential for employing solar energy technologies $[13,14]$. Moreover, Middle Eastern countries benefit from abundant resources of oil and gas, the region's energy depending highly on fossil fuels [15], i.e., renewable energies produced less than 1\% of the region's energy demand in 2018 [16]. In addition, the Middle East is a suitable site for constructing SWHS due to its arid and hot climate. In this context, there has been an investment growth in SWHS within the past few years, e.g., 2 million USD was invested in 2016, which is expected to rise by 0.5 million USD by the end of 2024 [17]. Due to the lack of electricity in midsummer in most countries, several governments have also focused on establishing grant policies for photovoltaic (PV) systems which brings negative impact on development of SWHS. Hence, although SWHS has been exploited moderately in most of the region's countries due to the low energy cost and electricity priority, this technology has been developed at a steady pace in a few countries, Turkey and Lebanon for instance [18]. Further, flat plat collectors (FPC) and evacuated tube collectors (ETC) are the main types of solar collectors used in the Middle East regarding the high solar fraction [19].

Various research has investigated the status of solar energy developments and investments in the Middle East [20-22]. However, a comprehensive review focusing on the techno-economic feasibility of SWHS has not been reported so far. Therefore, this paper aims to cover the major studies conducted on SWHS in the Middle East region with a broad view from its early stages to the recent progress. In this regard, the main research and results of techno-economic analysis of SWHS have been reviewed for every country and possible solutions to boost its development have been proposed. The main advantages of the presented work can be summarized as:

- Presenting the techno-economic analysis of the SWHS in the Middle East for the first time.

- Proposing various guidelines to extend this technology in the Middle East region. 
- Providing a roadmap for the region's countries to apply a convenient incentive framework regarding the local economic and meteorological conditions.

The remainder of the paper is structured as follows. The SWHS structure and its classification are elaborated in Section 2. Afterwards, the development of SWHS in Middle Eastern countries has been investigated in Section 3. In this regard, the solar energy potential of each country as well as the main research and progress of SWHS have been explored. Finally, the challenges, barriers, and possible solutions for future improvements have been presented in Section 4.

\section{Solar Water Heating System Structure and Classifications}

The simple structure of SWHS generally incorporates basic elements such as solar collector panels, a water storage tank, and a heat transfer medium [23,24]. It also includes a few additional components such as a pump, backup heating module, piping units, and a heat exchanger. In SWHS, the working fluid is heated through the sunlight beams and then stored in a storage unit. This heated fluid is subsequently transported in the pipes to satisfy the defined application, i.e., space heating and DHW usages. Conventionally, the SWHS uses solar radiation to heat the fluid; however, the storage unit exploits an auxiliary heater in some cases to compensate for the insufficient solar radiation of winter and cloudy days through the electricity or gas [23].

According to the structure, the SWHS is divided into the direct and indirect systems. In the prior, the water is pumped directly between the storage tank and solar collectors. In the latter, a heat transfer fluid, such as a glycol or water mixture, is passed among the collector, and a heat exchanger is used to support and accelerate the heat exchange from the collectors to the stored water. In these indirect systems, the heat exchanger is located inside or outside of the water tank [23].

The SWHS is also classified into the active and passive systems as shown in Figure 2 [24]. In the active system, including open- and closed-loop systems, the collectors, storage units, and distribution equipment are employed to absorb the solar radiation, store solar energy, and transfer it to the heated space, respectively (Figure 3). On the contrary, the passive systems are based on natural convection heat transfer using the thermosiphon method and integral collector storage. Moreover, the solar collector and storage unit are integrated into a building [25]. In the passive systems, heat is conducted naturally from the collector, installed at a higher elevation, toward the storage tank while in the active system, a pump is used to circulate the heating fluid across the collector. Although the active SWHS is more efficient even in multistory buildings, the complicated structure and higher cost are known as its two main demerits [26].

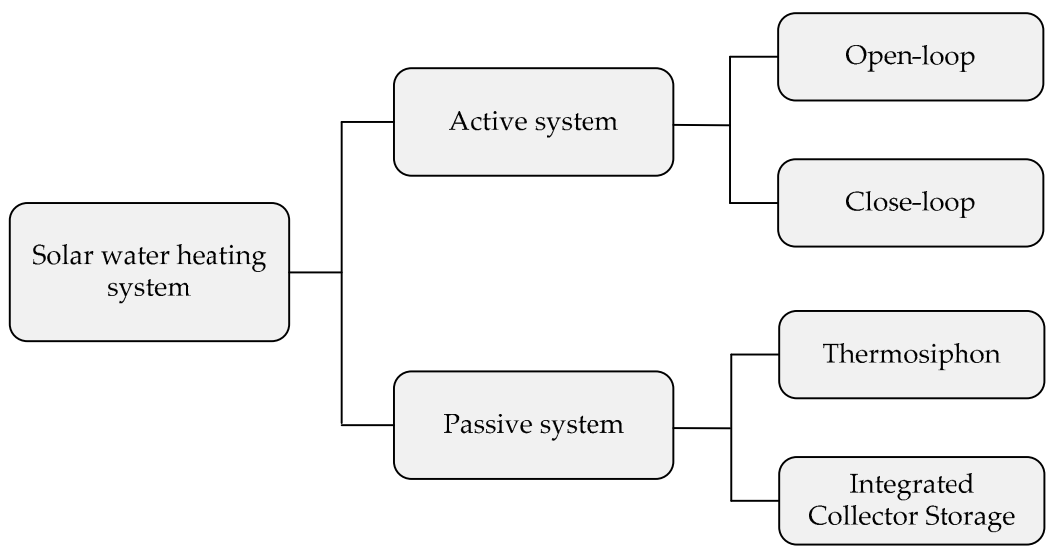

Figure 2. Various categories of solar water heating systems [24]. 


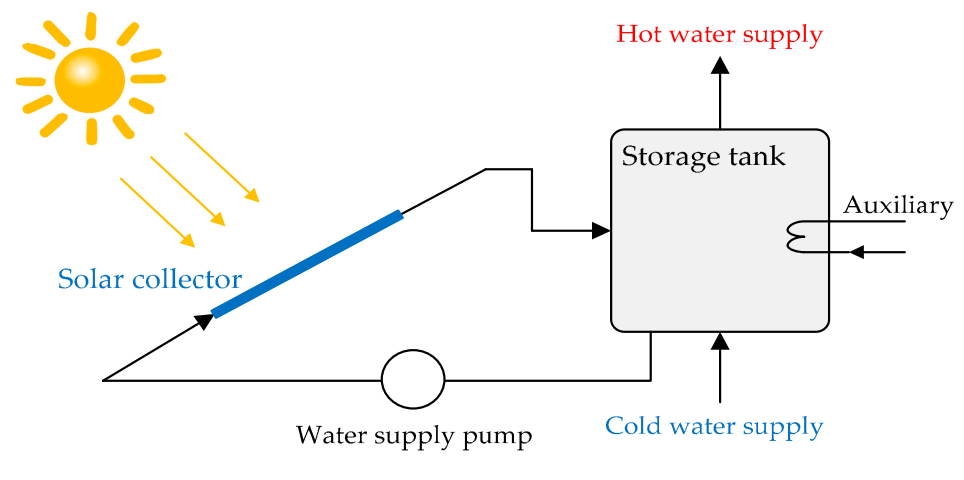

(a)

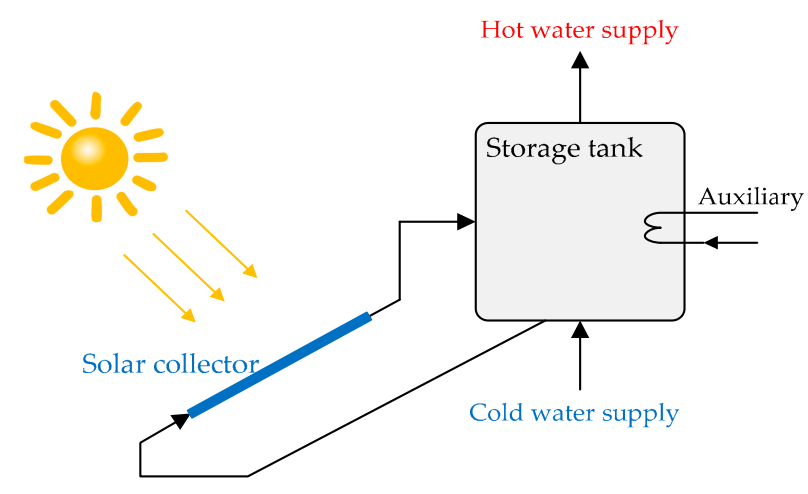

(b)

Figure 3. Schematic of SWHS: (a) active, (b) passive [25].

It is worth mentioning that there are some other types of solar passive systems which have not been equipped with solar collectors and other heating elements in buildings. There are several structures for such systems, e.g., installation of the piping systems through an enhanced wall with sufficient isolation reduces the annual heating energy demands of a building by $50 \%$ [27]. It is also possible to have a passive solar heating system with a water thermal storage wall to adjust the indoor temperature directly, without installation of the SWHS elements [28].

\section{Solar Water Heating Systems Developments in the Middle East}

The Middle East region consists of 18 countries with diverse geographical condition from arid areas to tropical or even cold climates [16,21]. According to the World Bank statistics given in Figure 4, energy use ( $\mathrm{kg}$ of oil equivalent per capita) and $\mathrm{CO}_{2}$ emissions in the Middle East have risen constantly within the past years [29]. Hence, the development of renewable energy technologies is mandatory in the area for mitigating the possible environmental issues and energy scarcity in the future. Luckily, most countries benefit from a plentiful potential of solar energies, as depicted in Figure 5 [30]. The average solar radiation intensity of these countries lies between $2000-3200 \mathrm{kWh} / \mathrm{m}^{2} /$ year, implying a high potential to apply solar energy technologies (Figure 6) [31].

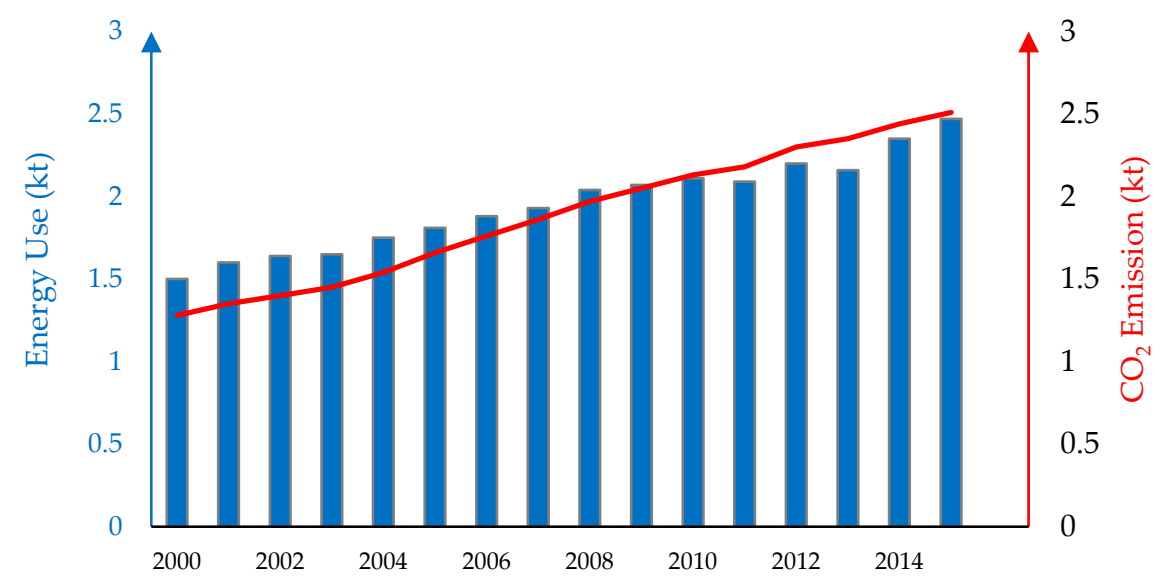

Figure 4. Growth trend of energy use vs. $\mathrm{CO}_{2}$ emissions in the Middle East [29]. 


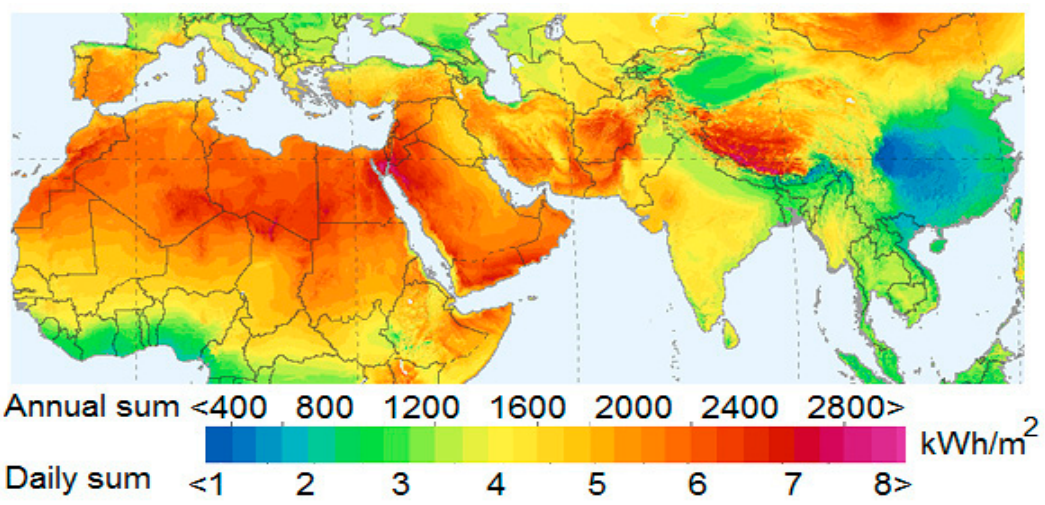

Figure 5. Solar irradiance distribution across the Middle Eastern countries. Reprint with permission [30]; 2021, Solargis.

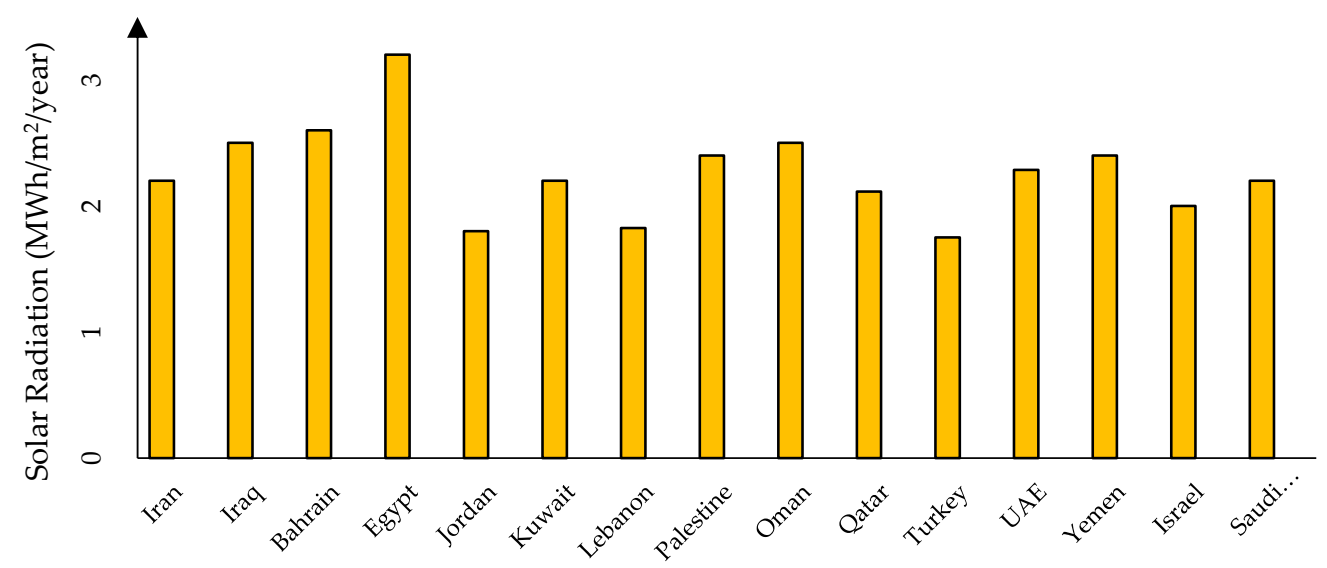

Figure 6. Annual average solar radiation of the Middle Eastern countries [31].

In major parts of the Middle East, the summer is scorching while the winter is very dry and cold (Figure 7) [32]. Although the SWHS may not be needed during the hot days for providing hot water or space heating, it can be used for water desalination, water pasteurization, and wastewater disinfection. The SWHS is also a suitable technology for supporting the growing demand on winter days. Thus, the techno-economic feasibility of SWHS in the Middle East region has drawn the attention of many scholars. In this paper, the recent research has been reviewed and thoroughly analyzed for every country, despite a few studies with a lack of pertinent research.

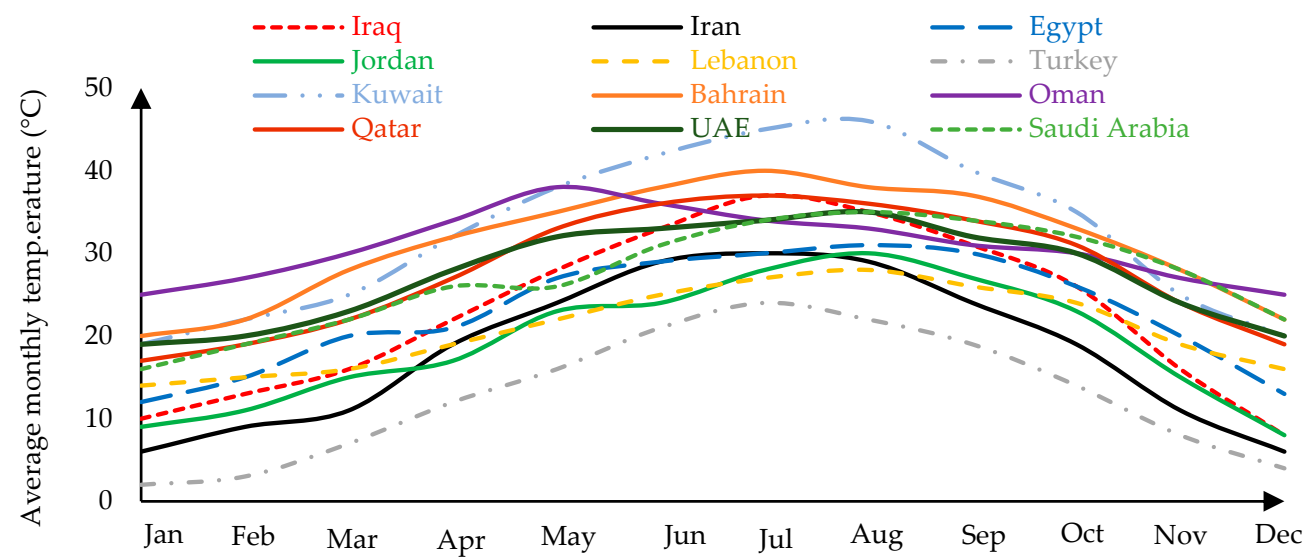

Figure 7. Average monthly temperature of the Middle Eastern countries [32]. 


\subsection{Solar Water Heating Systems in Iran}

Iran lies between the $25-40^{\circ} \mathrm{N}$ latitudes and $45-60^{\circ} \mathrm{E}$ longitudes and receives 1800 to $2200 \mathrm{kWh} / \mathrm{m}^{2} /$ year of solar energy, with average irradiation of $4.5-5.4 \mathrm{kWh} / \mathrm{m}^{2} /$ day on the flat surface. The average yearly global radiation of Iran's sunshine is $19.23 \mathrm{MJ} / \mathrm{m}^{2}$, which reaches further than $7.7 \mathrm{~h} /$ day in its middle parts. It is mentioned that there are almost 300 sunny days per year which is worth considering [33]. Therefore, Iran has abundant solar potential for installing SWHS; this potential has not been sufficiently exploited, however. The country has the highest natural gas reservoirs in the Middle East and almost $40 \%$ of the annual energy consumption belongs to the building sector, wherein $80 \%$ is used in the residential sector for providing DHW and space heating [34]. As is demonstrated in Figure 8, the hot water requisition in the summertime is at the minimum level, whilst there is more need for space heating and domestic usages during the other periods of the year [35].

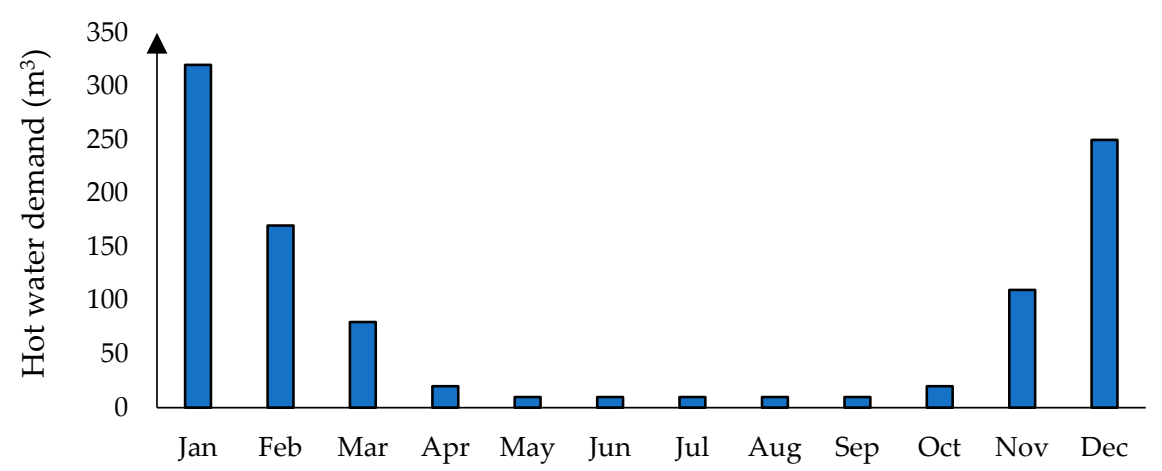

Figure 8. Monthly hot water demand for space heating and domestic uses in Iran [35].

Several researchers have concentrated on the feasibility of SWHS in various locations of Iran to diminish fossil fuel consumption and $\mathrm{CO}_{2}$ emission [36-44]. Karimi et al. simulated solar-powered underfloor heating systems in three distinct Iranian cities with different climate patterns [36]. The solar thermal system incorporates three major parts, including solar collectors, water tanks, and piping systems. There is also a natural gas-based backup boiler to attain the desired temperature when the water temperature is not in the desired range. The simulation results for a $12,000 \mathrm{~m}^{2}$ hotel building in the Design-Builder platform indicate that the fuel consumption reduces in the building during the December to February time frame, i.e., 125.39, 303.58, and 1.41 MWh for Tehran, Tabriz, and Kish, respectively. The results of the economic assessment implied that the payback period of the presented system is 8.2, 9.4, and 12.1 years for Tehran, Tabriz, and Kish, respectively.

The viability of a thermosiphon SWHS for supplying hot water demand has been studied experimentally in a northern city of Iran with a mild and humid climate [37]. The analyses have been performed for a clear and partially clear day in the ambient temperature below $0{ }^{\circ} \mathrm{C}$ during the autumn. In addition to the storage tank and collectors, the proposed system exploited two flat-plate collectors and a mantle heat exchanger horizontal cylindrical storage to supply the hot water requirements of a family house. The results highlighted that the system can be used for $8.5 \mathrm{~h}$ per day as an active system. It has also been shown that solar irradiation fluctuation has an insignificant effect on the tank average temperature during the day.

Hematian et al. presented the appraisal of a solar-assisted heating pump (SAHP) for heating a semi-solar house [38]. The research proposed both experimental and theoretical studies on a SAHP in an agricultural greenhouse located in a northwest city of Iran. The main system parts are a flat-plate solar collector, a water tank, an evaporator, and a pistontype compressor. The coefficient of performance (COP) and system efficiency are the most important parameters in the research which have been analyzed in the SAS9.1 platform. The indoor temperature with and without a solar backup heat pump has been tested to achieve the desired temperature of $15^{\circ} \mathrm{C}$. The results demonstrated that COP varies inside 
the 3.64 to 4.48 range according to the experimental and simulated model of the system. In addition, it has been deduced that the solar collector momentum, evaporator area changes, solar insolation, environment temperature, and collector covers may affect the system performance. Nevertheless, the SAHP application is technically and economically viable in the greenhouse. Finally, the authors stated that regarding the high sunshine of the system site, the $15 \mathrm{~m}^{2}$ greenhouse temperature reaches $16^{\circ} \mathrm{C}$ with $1 \mathrm{~m}^{2}$ collectors as an auxiliary system.

Since gas packages supply DHW and heating demand in Iran, the annual DHW and heating loads rely heavily on gas bills which is about $300 \mathrm{kWh} / \mathrm{m}^{2} /$ year energy. Hence, Shaddel and Shokouhi recommended a solar thermal system for supplying DHW and space heating of 136 flat apartments in Mashhad [39]. The developed system includes a rooftop glazed liquid flat-plate collector with two separate water paths for space heating and washing demands. The main system is supported by a gas heater in winter/cloudy times. The analysis showed that $68 \%$ of the DHW and $20 \%$ of the heating space demand can be supported by solar absorbers annually. Further, this system avoids $380 \mathrm{t} / \mathrm{year}$ of $\mathrm{CO}_{2}$ emissions and has a total annual fuel saving of $1015 \mathrm{~kg}$ for the whole case study. The authors presented a descriptive-analytic study on using solar water heaters in a four-floor residential apartment with eight units over a year in another study conducted for the same location. According to the results, the $\mathrm{CO}_{2}$ emissions will be reduced to around 178 tons within the system operating time [40].

Various parameters regarding the use of SWHS in the Yazd province of Iran have been identified and prioritized by Qolipour et al. [41]. These critical factors are linked to the design, implementation, and operation of SWHS. Several factors related to economic, environmental, and geographical issues as well as social, cultural, and political problems have been recognized. The outputs indicated that the environmental issues affect the use of SWHS notably. From an economic standpoint, the incentive policy of the government has the highest influence on SWHS development.

In [42], the techno-economic assessment of a typical dwelling hybrid water heating system (HWHS) for DHW and space heating in Shiraz was carried out. Governmental plans, incentive programs, and climate conditions have been included in the modeling of HWHSs in the residential sector. The authors modeled a five-floor building with a total area of $580 \mathrm{~m}^{2}$ and 20 occupants as a case study. The system consists of solar collectors and the piping system as the heat exchanger, storage tank, and electricity with a natural gas-based auxiliary system. The results confirmed that the DHW demand is a vital parameter in hybrid solar water heater systems' performance. The system performance can also be enhanced by an optimum selection of the water tank capacity and the number of solar collectors. In addition, the system cost diminishes by around $45 \%$ through exploiting a space heating system under the most economic design.

An energy- and exergy-based study of a novel SWHS with a plenary thermodynamic model has been reported [43]. The recommended system which includes a solar evaporator, a heat exchanger, a heat piping system, and an auxiliary pump has been adopted to provide hot water in the cold seasons. The authors indicated that the utmost sources of exergy destruction in the SWHS are the solar evaporator $(92.85 \%)$ and heat exchanger $(4.15 \%)$, respectively. Further, it has been inferred that the overall energetic and exergetic efficiencies of the proposed system are $60.17 \%$ and $3.00 \%$, respectively. In addition, a solar loop heat pipe system can transfer the heat flux effectively for improving the efficiency of the whole system.

Based on the presented studies, an efficient solar thermal system is economically viable in Iran by upgrading the grid infrastructure and implementing commercial renewable energy systems for buildings as tabulated in Table 1. The government policies for developing renewable energy systems are defined by the ministries of energy and petroleum in which the installed capacity of renewable energies should rise by 5\% in 2021 [45]. However, the low cost of energy is the main limitation for this development. 
Table 1. Summary of solar water heating system research and projects in Iran.

\begin{tabular}{|c|c|c|c|c|c|c|}
\hline System Type & Location & Case Study & Usages & System Spec. & $\begin{array}{c}\mathrm{CO}_{2} / \text { Fossil Fuel } \\
\text { Reduction }\end{array}$ & Payback Time \\
\hline HWHS [35] & Shiraz & $\begin{array}{l}\text { Five-floor } \\
\text { residential } \\
\text { building } \\
\text { with } 580 \mathrm{~m}^{2} \text { area }\end{array}$ & $\begin{array}{c}\text { DHW and Space } \\
\text { Heating }\end{array}$ & $\begin{array}{c}5 \mathrm{~m}^{2} \text { solar } \\
\text { collector with } \\
50 \mathrm{~m}^{3} \text { water tank }\end{array}$ & - & $\begin{array}{c}7 / 11 \text { years with } \\
\text { gas/electric } \\
\text { backup }\end{array}$ \\
\hline $\begin{array}{l}\text { Solar Powered } \\
\text { Underfloor } \\
\text { Heating [36] }\end{array}$ & $\begin{array}{l}\text { Tehran } \\
\text { Tabriz } \\
\text { Kish }\end{array}$ & $\begin{array}{c}\text { Hotel } \\
\text { with } 12,000 \mathrm{~m}^{2} \\
\text { area }\end{array}$ & Space Heating & $\begin{array}{l}968 \mathrm{~m}^{2} \text { flat plate } \\
\text { collectors }\end{array}$ & $\begin{array}{c}\text { 125.39 MWh } \\
\text { 303.58 MWh } \\
\text { 1.41 MWh }\end{array}$ & $\begin{array}{c}8.2 \text { years } \\
9.4 \text { years } \\
12.1 \text { years }\end{array}$ \\
\hline $\begin{array}{c}\text { Solar Thermal } \\
\text { System [39] }\end{array}$ & Mashhad & $\begin{array}{c}68 \text { residential flats } \\
\text { with an area of } \\
220 \mathrm{~m}^{2} / \text { flat }\end{array}$ & $\begin{array}{l}\text { Space Heating } \\
\text { and DHW }\end{array}$ & - & 380 tons/year & 4 years \\
\hline $\begin{array}{l}\text { Solar Water } \\
\text { Heaters [40] }\end{array}$ & Mashhad & $\begin{array}{l}\text { Four-floor } \\
\text { residential } \\
\text { building }\end{array}$ & Space Heating & $\begin{array}{l}6.84 \mathrm{~m}^{2} \text { solar } \\
\text { collector }\end{array}$ & $\begin{array}{c}178 \text { tons } \\
\text { (9.7 Ton/year) }\end{array}$ & 7.5 years \\
\hline Reference [42] & $\begin{array}{l}31 \text { Provincial } \\
\text { Capitals }\end{array}$ & - & Space Heating & $\begin{array}{c}4.45 \mathrm{~m}^{2} \text { solar } \\
\text { collector with } \\
300 \mathrm{~m}^{3} \text { water tank }\end{array}$ & $1476-2491 \mathrm{~kg}$ & 8 years \\
\hline
\end{tabular}

\subsection{Solar Water Heating Systems in Iraq}

Iraq's climate is classified by a moderate winter with a minimum temperature of $5{ }^{\circ} \mathrm{C}$ and a hot and dry summer with a maximum temperature of $45^{\circ} \mathrm{C}$. The daily sunshine period of Iraq varies from 7 to $12 \mathrm{~h}$ in winter and summer, respectively. The average daily solar irradiance is $6.5-7 \mathrm{kWh} / \mathrm{m}^{2}$ and the total annual sunshine period is at least $2800 \mathrm{~h}$ [46]. The lack of power supply in Iraq, the abundant sunshine hours throughout the year, and the reasonable cost of the system are the motivations to install the SWHS to meet domestic and industrial hot water demands [47]. As is indicated in Figure 9, the daily average of the required energy for different volumes of hot water in winter is more than the other months. In this figure, Qhw and Vhw represent the quality and volume of the hot water, respectively [48]. Accordingly, various techno-economic analyzes of SWHS have been conducted [49-54].

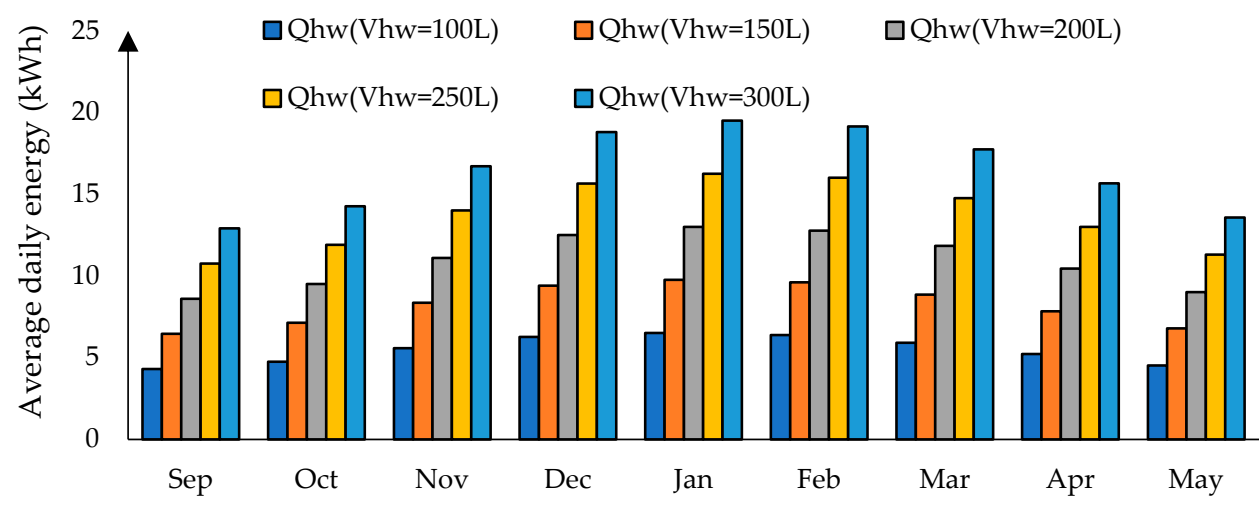

Figure 9. Average daily required energy for different volumes of hot water in Iraq (kWh) [48].

Al-Shamkhee et al. studied a SWHS with flat plate collectors (FPCs) in Najaf city [49]. The closed-loop system with the direct flow for space heating has been exploited and the collector efficiency and the maximum temperature of the collector's water have been estimated. What stands out from the experimental outputs over a year interval is how several meteorological factors such as ambient temperature and solar irradiance intensity affect the collector's efficiency, e.g., the collector's daily efficiency and its hot water temperature peaked at $37.16 \%$ and $57.1{ }^{\circ} \mathrm{C}$, respectively.

A forced circulation solar thermal system for providing DHW in Basrah and Baghdad has been developed by Al-Madhhachi et al. [50]. In the presented system, a solar thermal 
FPC, storage tank, circulation pump, and controller have been employed. It is seen that the monthly collector efficiency peaks at $69 \%$ and $54 \%$ in Baghdad and Basrah in summer, respectively. The minimum sets in winter are also $62 \%$ and $51 \%$ in Baghdad and Basrah, respectively. In winter, the solar fraction in Basrah with an average value of $66 \%$ is greater than the corresponding Baghdad set. Furthermore, the maximum auxiliary energy in Baghdad is greater than Basrah's one during the winter days. Finally, the authors showed that the deployment of the isothermal layers in the storage tank leads to $6-8 \%$ higher collector efficiency.

Hashim et al. conducted experimental research on the performance of SWHS with FPCs in Baghdad [52]. The results unveiled that a lower water flow rate results in a higher temperature and greater efficiency. In order to find a model and variety of a direct SWHS in the cold winter days of Baghdad, a system with an auxiliary electrical heater based on $69 \%$ annual solar fraction has been established [53]. It is shown that the required auxiliary energy peaks at $1025 \mathrm{MJ} /$ month in December, while it is at the minimum of $1000 \mathrm{MJ} /$ month in February. Moreover, a $6.5 \%$ rise in the solar fraction is seen by extending the solar collector area from $10 \mathrm{~m}^{2}$ to $40 \mathrm{~m}^{2}$.

As summarized in Table 2, it can be concluded that SWHS is a reliable technology in Iraq for supporting DHW and space heating with acceptable system efficiency. Further, an auxiliary heating system is mandatory during winter to compensate for the insufficient received solar radiation. However, there is a lack of information about Iraqi government policies regarding developing SWHS in the country.

Table 2. Solar water heating system research and projects in Iraq.

\begin{tabular}{|c|c|c|c|c|}
\hline System Type & Location & Testing Period & System Spec. & $\begin{array}{l}\text { Usages (Max. } \\
\text { Collector/Tank } \\
\text { Reached Temp.) }\end{array}$ \\
\hline SWHS with FPC [49] & Najaf & January & $\begin{array}{l}60 \mathrm{~L} / \mathrm{h} \text { water consumption } \\
\text { with } 2 \mathrm{~m}^{2} \text { collector }\end{array}$ & Space heating $\left(57.1^{\circ} \mathrm{C}\right)$ \\
\hline $\begin{array}{l}\text { Forced Circulation } \\
\text { SWHS [50] }\end{array}$ & $\begin{array}{l}\text { Baghdad } \\
\text { Basrah }\end{array}$ & A year & $\begin{array}{l}10 \mathrm{~m}^{2} \text { collector with } 0.8 \mathrm{~m}^{3} \\
\text { tank } \\
100 \mathrm{~L} / \text { person hot water } \\
\text { consumption }\end{array}$ & $\mathrm{DHW}\left(50^{\circ} \mathrm{C}\right)$ \\
\hline SWHS [51] & Hillah & April to June & $\begin{array}{c}1.5 \mathrm{~m}^{2} \text { collector area with } \\
50 \mathrm{~L} \text { tank }\end{array}$ & $\operatorname{DHW}\left(67.3^{\circ} \mathrm{C}\right)$ \\
\hline SWHS with FPC [52] & Baghdad & - & $1.37 \mathrm{~m}^{2}$ collector area & Space heating $\left(51.4^{\circ} \mathrm{C}\right)$ \\
\hline SWHS [53] & Baghdad & Winter & $\begin{array}{c}10 \mathrm{~m}^{2} \text { collector with } 600 \mathrm{~L} \\
\text { tank and 25-person } \\
\text { consumption }\end{array}$ & $\mathrm{DHW}\left(68^{\circ} \mathrm{C}\right)$ \\
\hline SWHS [54] & Baghdad & $\begin{array}{l}\text { 1st of November and } \\
\text { 31st of March }\end{array}$ & $\begin{array}{c}10 \mathrm{~m}^{2} \text { collector with } 0.3 \mathrm{~m}^{3} \\
\text { tank }\end{array}$ & $\begin{array}{c}\text { Space heating }\left(48^{\circ} \mathrm{C} \text { in }\right. \\
\text { December and } 55^{\circ} \mathrm{C} \text { in } \\
\text { March) }\end{array}$ \\
\hline
\end{tabular}

\subsection{Solar Water Heating Systems in Egypt}

Egypt is located in the sun-belt area, covered by abundant direct solar irradiance ranging between $2000-3200 \mathrm{kWh} / \mathrm{m}^{2} /$ year [55]. Besides this, more than $22 \%$ of the energy in Egypt is consumed in the building sector. For instance, the total monthly hot water and space heating loads for a multi-family dwelling in the capital, Alexandria, is shown in Figure 10 [56]. It is evident that the hot water and space heating loads are greatest during the wintertime. Thus, the SWHS is one of the most well-known approaches to reduce the consumption of conventional energy resources such as electricity, oil, and liquefied petroleum gas. It is estimated that the annual $\mathrm{CO}_{2}$ emissions would be diminished more than 4.5 million tons, whilst the hot water demand in the residential sector would be fully supported by solar energy [57]. The use of SWHS in Egypt started in the late 1970s and 
early 1980s; however, this market is still in its primary stages, and using solar thermal applications for either heating processes or power generation is quite limited [58].

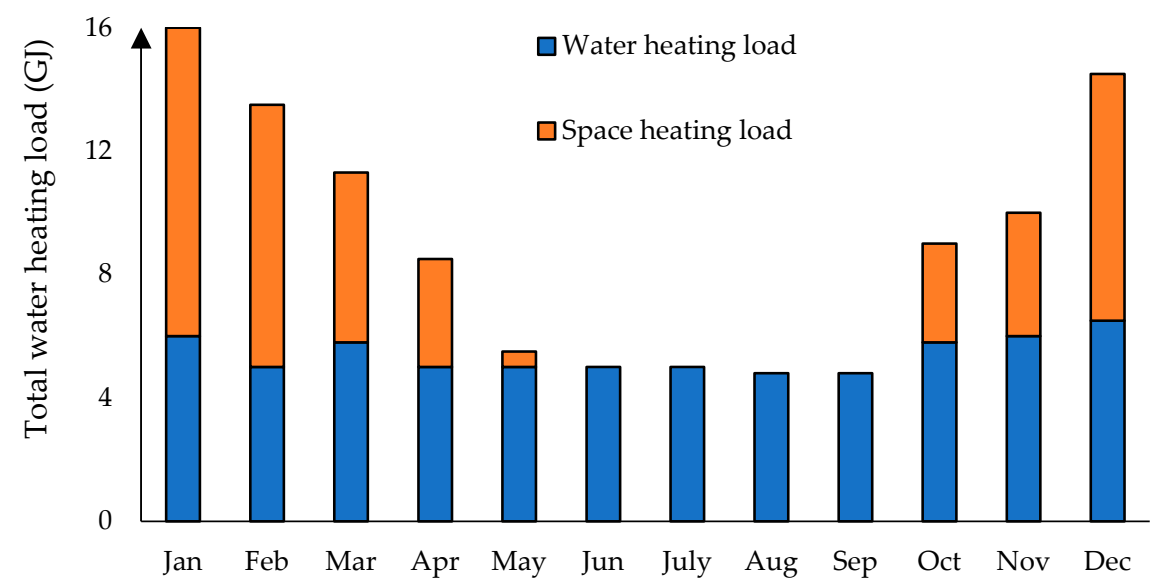

Figure 10. Overall monthly heating demand of a multi-family dwelling in Alexandria [56].

A techno-economic feasibility study of SWHS in Egypt has been reported $[56,59,60]$. The immediate efficiency of two different FPCs, AST, and KOPF has been examined by Ghoneim et al. [56]. In the presented work, an SWHS has been designed to provide both water and space heating requirements of a multi-family house using the estimated parameters of the collector tests. The system comprised of a solar flat collector, electrical heating to compensate the water at room temperature, direct preheat and auxiliary tanks, and a pump. According to the provided outputs, the solar fraction is improved by increasing the collector area up to "50 and $40 \mathrm{~m}^{2}$ for AST and KOPF" collectors, respectively. It is also shown that the life-cycle savings would be raised from 12,100 to 14,000 USD through the AST collectors, i.e., the proposed SWHS is economically practical accordingly.

Atia et al. established a forced-circulation SWHS model to provide hot water at a reference temperature for an aquaculture system [59]. The size of the FPC and the auxiliary heater has been defined optimally by a genetic algorithm to achieve the minimum system cost over 20 years. The optimal collector area has been found to be $63 \mathrm{~m}^{2}$ and the solar fraction reached $98 \%$, which is enough for load demands. Since the aquaculture system operates during summer and winter, the average value of the solar fraction has been reported for these seasons. It was seen that above $90 \%$ of the hot water needs would be supplied during summer (May to September) by the solar heating system where the solar fraction is 68.1-99\%. During the winter, the solar fraction has a minimum value between 44.9-92.8\% where an auxiliary heater would be employed to satisfy the desired temperature with a higher system cost.

In Egypt, one of the major obstacles to applying the SWHS is the high initial costs, i.e., $56 \%$ of system components or raw materials are fully imported and around $33 \%$ are partially imported. Additionally, there are political, financial, social, and economic barriers to the use of SWHS. In order to facilitate the deployment of SWHS, various recommendations have been established. For instance, it was revealed in [60] that SWHS design techniques should be performed considering the component characteristics as well as geographic location, system size and cost, and maintenance protocols. The SWHS configurations in a residential building such as wall-combined, roof-combined, and balcony-combined should also be taken into account during the architectural design process of the building.

Based on the conducted research summarized in Table 3, although using SWHS in Egypt is practical due to its high solar energy potential, there are some challenges in developing this technology. The high initial costs, low electricity price, lack of government support, and public awareness are the main obstacles in this way. Although the statistics show that more than $750,000 \mathrm{~m}^{2}$ SWH has been installed in Egypt by 2013, which could be 
the results of government policies in developing this technology, the current situation is far from the desired goal [61].

Table 3. Solar water heating system studies and projects in Egypt.

\begin{tabular}{|c|c|c|c|c|c|}
\hline System Type & Location & Testing Period & Building Area & System Spec. & Usages \\
\hline SWHS [58] & Alexandria & $\begin{array}{l}\text { September and } \\
\text { October }\end{array}$ & $576 \mathrm{~m}^{2}$ four floor & $\begin{array}{l}\text { Hot water demand for } \\
40 \mathrm{~kg} / \text { day/person, water } \\
\text { flow rate } 0.02 \mathrm{~L} / \mathrm{m}^{2} \mathrm{~s}+ \\
10 \%, 5.92 \mathrm{~m}^{2} \mathrm{AST} \text { collector } \\
\text { and } 2.53 \mathrm{~m}^{2} \mathrm{KOPF} \\
\text { collector }\end{array}$ & $\begin{array}{l}\text { Space Heating } \\
\text { and DHW }\end{array}$ \\
\hline $\begin{array}{l}\text { Forced circulation } \\
\text { SWHS [59] }\end{array}$ & Mersa Matruh & $\begin{array}{l}\text { Summer } \\
\text { Winter }\end{array}$ & $\begin{array}{l}\text { Aquaculture } \\
\text { system }\end{array}$ & $\begin{array}{c}\text { Optimal collector area is } \\
\text { equal to } 63 \mathrm{~m}^{2}\end{array}$ & $\begin{array}{l}\text { Hot water for } \\
\text { aquaculture } \\
\text { pool }\end{array}$ \\
\hline
\end{tabular}

\subsection{Solar Water Heating Systems in Jordan}

Thermosiphon SWHS is used widely in Jordan for DHW usages regarding the country's high potential of solar energy, i.e., the annual received radiation is $1800 \mathrm{kWh} / \mathrm{m}^{2} /$ year. As is displayed in Figure 11, the hot water demand in the capital of Jordan, Amman, is more than $1000 \mathrm{MJ}$ wherein the SWHS can be employed [62].

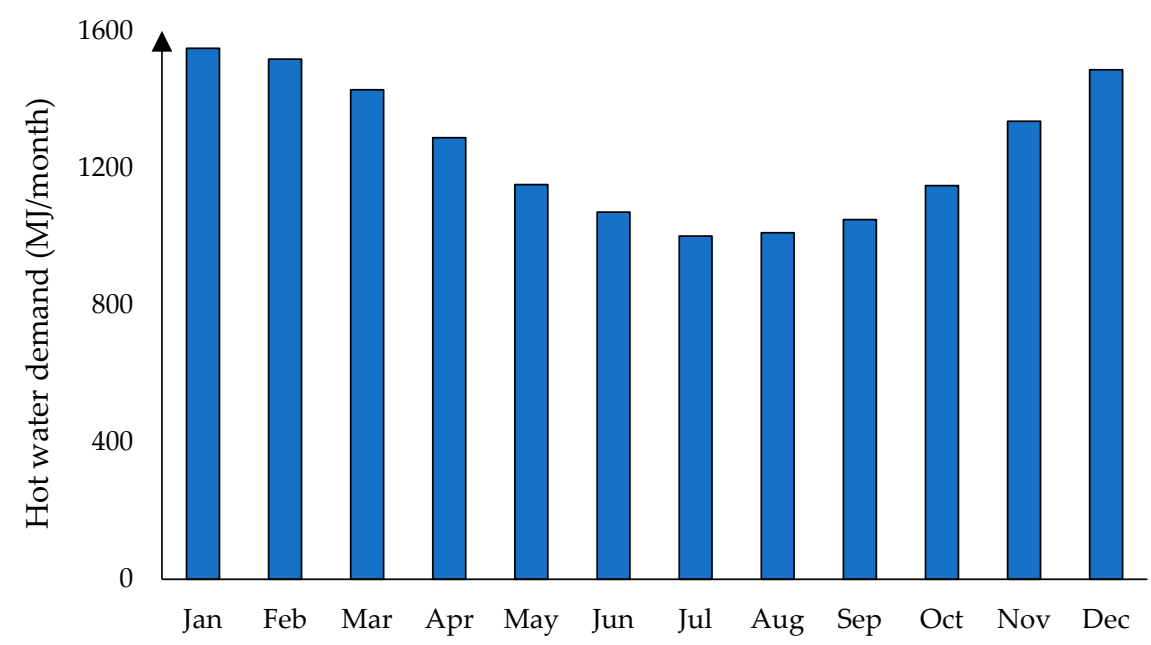

Figure 11. Monthly hot water heating demand in Amman [62].

The solar water heating market in Jordan was initiated after the oil crisis in 1973 [63]. SWHS is evolving so rapidly that 30\% of families had installed this technology by 2015. This technology has gained research attraction as well [64-68].

A design parameter optimization for a thermosiphon SWHS in two cities of Amman and Aqaba with mild and hot climates has been performed to augment the annual solar fraction [64]. In the presented system, a flat-plate collector, water tank, thermostat, flow mixer, piping system, and an auxiliary heater have been employed. The effect of several variables, such as collector number, riser spacing, riser diameter, storage tank height, height of the return pipe from the collector to the storage tank, height of the auxiliary heater, thermostat, and the total heat loss coefficient of the water tank on solar fraction, have been assessed and afterwards, the optimum sets for both cities have been quantified. The outputs showed that the solar fraction improves by $7-25 \%$ depending on the design parameters. It was also inferred that selecting the optimum sets for a thermosiphon system mitigates the system costs and improves its performance.

Mohsen and Akash introduced Jordan as a pioneer country in the Middle East by installing more than 300,000 solar water heaters which provide around 30\% of its DHW 
demand [65]. This granted a $2 \%$ saving of total oil imports, a saving of 6 million Jordanian Dinars. It is estimated that just $70 \mathrm{ktoe} /$ year of energy could be currently generated by these systems, whilst there would be a need for having an additional 500,000 dwelling units within the next 20 years. The authors emphasized promoting passive solar energy efficiency and building regulations, evaluation of solar panels' efficiency and design integrity, and investigation in SWHS in multi-dwelling buildings to raise SWHS installation in Jordan. It is also mandatory to remove the price barriers and develop a national industry to fully exploit the renewable energy potential of the country.

The financial evaluation of SWHS and conventional water heating systems in Jordan has been proposed [66]. The results would help decision-makers to determine an optimum heating system in Jordan based on its economic indices. The benefits included all possible privileges which can be gained from SWHS. The cost criteria are defined in terms of moneyvalue or costs such as fuel cost, equipment cost, repair and maintenance, backup system, and environmental limits. The authors stated that SWHS has the minimum efficiency and reliability, highest hardware cost, and greatest demand for an auxiliary system among the existing alternatives.

The thermal performance and life energy cost of an SWHS for a swimming pool in west Amman in Jordan have been evaluated in [67]. SWHS regulates the swimming pool's water temperature which alleviates the conventional energy costs. The system type is similar to other SWHS despite the fact that the swimming pool operates as the thermal storage instead of the water tank and the pool water is pumped directly through the solar collectors. The results unveiled that that thermal comfort is achievable for nine months, while an auxiliary heater would be needed to compensate for the water temperature from December to February. By this, the energy demand drops by $75 \%$, and the energy losses would be $77 \%$ due to evaporation. This loss can be lessened effectively by covering the pool during the night. From an economic standpoint, the payback period of the presented system would be around one year.

The SWHS and gas geyser system (GSS) are two competitive and reliable choices for providing hot water for domestic daily needs in Jordanian families. Although the GGS's installation costs are smaller than the SWHS's one, it accompanies several demerits such as gas explosion potential, pollution, operation lifetime, and negative economic impacts. Kablan compared an SWHS with an auxiliary electric coil, equipped with a GGS from the economic outlook [68]. The annual delivered energy for these two systems has been defined as the energy needed to provide the annual average hot water demand of Jordanian families. Therefore, the economic comparison between these systems has been carried out based on the systems' annual costs, including maintenance costs, the salvage value of the system, and annual fuel costs. The author showed that despite the higher initial costs, the SWHS has a longer optimal operation lifetime (20 years) in comparison with GGS (7 years). In addition, the SWHS is more economical than the conventional electricity-based water heating systems for less than 120 days per year, e.g., during January, February, March, and December. It was also recommended that government must define some motivation policies to encourage residents to exploit SWHS.

Conducted research has indicated that there are several barriers to expanding SWHS in Jordan, and according to the National Energy Efficiency Action Plan, more than 30,000 SWH must be installed by 2025 [63]. Lack of public awareness, lack of inventive policies, high installation prices, and great dependency on auxiliary systems are the major problems that must be taken into account. Table 4 summarizes the SWHS studies and projects in Jordan. 
Table 4. Summary of solar water heating system research and projects in Jordan.

\begin{tabular}{|c|c|c|c|c|c|c|}
\hline System Type & Location & $\begin{array}{l}\text { Testing } \\
\text { Period }\end{array}$ & $\begin{array}{l}\text { Building } \\
\text { Area }\end{array}$ & System Spec. & Usages & $\begin{array}{l}\text { Max. } \\
\text { Collector/Tank } \\
\text { Reached Temp. }\end{array}$ \\
\hline $\begin{array}{l}\text { Thermosiphon } \\
\text { SWHS [64] }\end{array}$ & Amman & A year & - & $\begin{array}{l}\text { Water Daily Load } 150 \\
\mathrm{~L} / \text { day and } 4 \mathrm{~m}^{2} \text { collector }\end{array}$ & $\begin{array}{l}\text { Space Heating } \\
\text { and DHW }\end{array}$ & $60^{\circ} \mathrm{C}$ \\
\hline $\begin{array}{l}\text { Thermosiphon } \\
\text { SWH [64] }\end{array}$ & Aqaba & A year & - & $\begin{array}{c}150 \mathrm{~L} / \text { day daily load and } \\
4 \mathrm{~m}^{2} \text { collector }\end{array}$ & $\begin{array}{l}\text { Space Heating } \\
\text { and DHW }\end{array}$ & $60^{\circ} \mathrm{C}$ \\
\hline SWHS [65] & Amman & $\begin{array}{l}\text { 7th } \\
\text { November to 24th } \\
\text { April. }\end{array}$ & $110 \mathrm{~m}^{2}$ & $\begin{array}{l}\text { Water daily load } \\
120 \mathrm{~L} / \text { day, } 40 \mathrm{~m}^{2} \text { collector } \\
\text { and } 2.5 \mathrm{~m}^{3} \text { Storage tank }\end{array}$ & $\begin{array}{l}\text { Space heating } \\
\text { and DHW }\end{array}$ & $\begin{array}{c}\text { November } 20.3^{\circ} \mathrm{C} \\
\text { January } 19.8^{\circ} \mathrm{C} \\
\text { March } 20.6^{\circ} \mathrm{C} \\
\text { April } 20.0^{\circ} \mathrm{C}\end{array}$ \\
\hline
\end{tabular}

\subsection{Solar Water Heating Systems in Lebanon}

As a small Mediterranean country, Lebanon is located at $33^{\circ} \mathrm{N}$ and $35^{\circ} \mathrm{E}$ with altitudes between $0-3000 \mathrm{~m}$, benefiting from a substantial amount of sunshine. The average daily solar radiation is between $2-6 \mathrm{kWh} / \mathrm{m}^{2}$ and the annual average solar radiation is $1825 \mathrm{kWh} / \mathrm{m}^{2}$ [69]. As is illustrated in Figure 12, there is a wide variation of hot water consumption in Lebanon, e.g., the lowest and highest sets in summer and winter times, respectively. This leads to a great electricity demand and associated costs for providing this hot water by conventional heating systems at most times of the year, as shown in this figure. Further, the average hot water consumption in Lebanon is $35 \mathrm{~L} /$ person, requiring a thermal heat of $618 \mathrm{kWh} /$ person/year [70]. More than $97 \%$ of the national energy is generated using imported fossil fuels, which causes an incline in energy bills. This leads to an increased economic dependency to the international oil price changes which affects public finances notably [71]. Lebanon promised to raise the clean energy share in its energy mix to just over $10 \%$ of the estimated electricity and heating demand by 2020 [72].

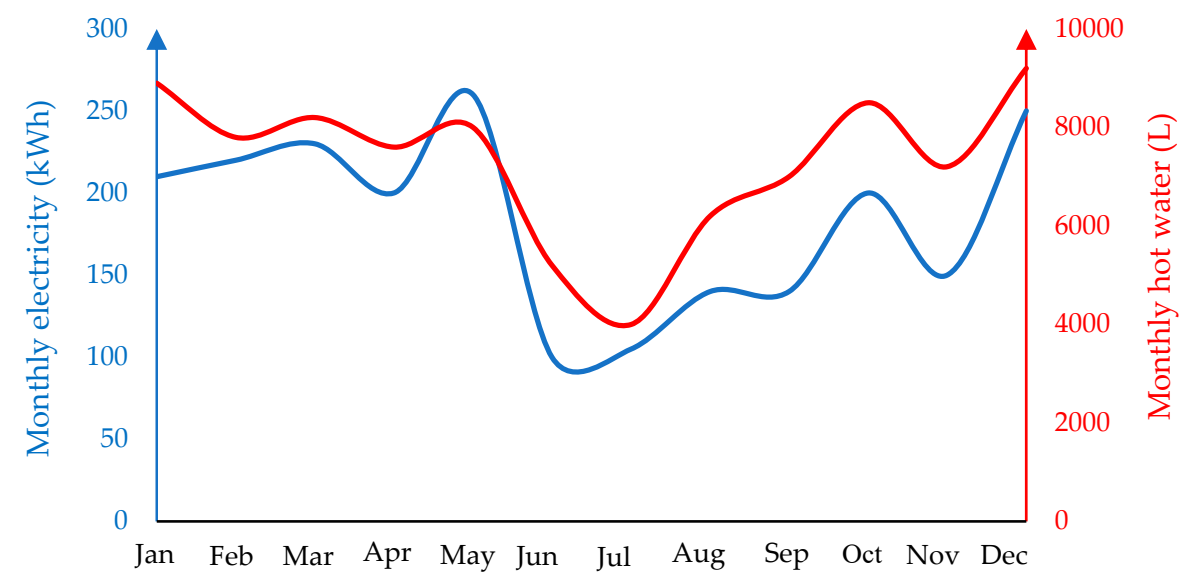

Figure 12. Monthly hot water vs. kWh consumption in Lebanon [70].

According to the high energy costs and significant solar potential, the SWHS has been developed more than other renewable energy technologies in Lebanon. In spite of installing $450,000 \mathrm{~m}^{2}$ of solar collector in the country, there is still a growing demand for SWHS [73]. By considering all, Lebanon has made great progress in the way of using SWHS across the country.

Houri et al. analyzed the experimental data of a SWHS at Marjeyoun, South Lebanon according to real measurements for a moderate-sized building [70]. The studied case has five residents with five rooms, as well as two bathrooms with a total area of $100 \mathrm{~m}^{2}$. The results revealed that SWHS provides approximately all $3092 \mathrm{kWh}$ of hot water demands between April and October and just 1.4\% of the energy is supported by an electrical heater, saving 195 USD/year. The obtained data showed that there is a saving limit in the proposed system and its payback period is long in the rural applications. 
Ruble and El Khoury studied the domestic SWHS market growth in Lebanon in the terms of newest developments, environmental effects, and electricity consumption [71]. The study has been carried out for three scenarios, namely, a baseline scenario that manifests projections in the term of electricity demand, RES- 1 in which SWHS is obligatory for newly constructed buildings, and RES-2 in which electric boilers will be replaced by SWHS in existing buildings, over the period of 2013-2027. It was concluded that electricity consumption goes up to 2430, 1550, and 1393 GWh by 2027 for water heating demands in BS, RES-1, and RES-2 scenarios, respectively. The penetration rate of domestic SWHS in the BS, RES-1, and RES-2 reaches 10, 58, and 67\% for this time being, respectively. Moreover, the government subsidies would be saved around 209 and 246 million USD for RES- 1 and RES-2, respectively. The avoided $\mathrm{CO}_{2}$ emissions would be also 674 and 572 kilo tones under the RES-1 and RES-2 scenarios.

Beih and Abou Chakra explored the phase change material (PCM) utilization in the domestic solar hot water storage tank (DSHWST) for improving hot water storing and the DSHWST's efficiency [73]. In this context, the DSHWST integrated with PCM has been compared technically with a conventional electrical resistance-based auxiliary heating system. In this case, a suitable Sodium Acetate Trihydrate PCM has been chosen which reacts in temperature range of $55-60{ }^{\circ} \mathrm{C}$ and keeps the water inside the tank warmer than $55^{\circ} \mathrm{C}$ for $10 \mathrm{~h}$. The results proved that using DSHWST with PCM reduces the primary electricity of a five-person family house by around $6.5 \mathrm{MWh} /$ year and 5.5 tons of $\mathrm{CO}_{2}$. However, because of the current high price of PCM in Lebanon, the payback period is about 20 years, i.e., the project is not economically practical.

There is a focus on the impact of the SWHS program, which was started in late 2010 and is realized currently through low-interest loans and subsidies [74]. It also provides a road map on the required future actions to enhance the momentum of the SWHS market. It is evident that the market in Lebanon has been developed markedly, in which $610,000 \mathrm{~m}^{2}$ of installation has been completed by December 2017. It is important to notice some barriers, such as building developers' willingness to locate SWHS in the constructing procedure and decent buyer costs. For example, there are high-rise buildings with limited roof space to construct SWHS for each apartment; accordingly, the buyers have to spend an additional cost to install this technology. It is still vital to educate customers to raise their awareness about the benefits of SWHS by pointing out that such a system is the most affordable thermal renewable energy technology on the market. With the integration of the existing installed surface area to the estimated market through 2020 and the solar ordinance prediction, the country's global SWHS surface area would be $1,248,708 \mathrm{~m}^{2}$, which is $200,000 \mathrm{~m}^{2}$ more than the set target. These SWHS would save annually around 743,000 MWh and 483 tons of $\mathrm{CO}_{2}$ emissions.

The research was conducted on the present status and prospects of SWHS in Lebanon [74]. It is indicated that the current installed capacity of SWHS is more than $100,000 \mathrm{~m}^{2}$ and there is a potential to implement more than 1.5 million $\mathrm{m}^{2}$ beyond this. The domestic sector has the highest potential of using such a system, and the SWHS market has been raised over the past years despite the existing barriers. SWHS has a long lifespan (around 20 years), and the payback period is less than 9 years at the current market price. However, payback periods are anticipated to alleviate dramatically with decreasing the collectors' costs per square meter.

Despite all progress and developments of SWHS in Lebanon, some challenges can be eliminated to accelerate the using expansion of this technology in the residential and industrial sectors. Long pay-back times, lack of technical knowledge, lack of decisionmaker awareness, and low subsidies are among the main issues.

\subsection{Solar Water Heating Systems in Turkey}

Turkey is located at the joint point of Asia, Europe, and Africa and links Asia and Europe together. The total population of Turkey with $779,452 \mathrm{~km}^{2}$ area was about 77 million in 2014. This country has an abundant solar energy potential with an average daily solar radiation intensity of $12.96 \mathrm{MJ} / \mathrm{m}^{2}$ and $7.2 \mathrm{~h}$ sunshine duration [75]. Household appliances 
consume $60 \%$ of the country's total energy for space heating. The annual solar thermal energy production in Turkey was $828 \mathrm{ktoe}$, and $65 \%$ of this energy is utilized in the residential sector for heating water. Regarding the high energy demand of the residential sector and the plentiful potential of solar energy in most regions, Turkey started the production of SWHS in 1980. Hence, the SWHS expansion in the local market grows gradually [76].

For technical and economic prospects, various studies have been conducted to illuminate SWHS viability as summarized in Table 5 [76-80]. Benli studied the solar water heater viability based on meteorological and geographical data from six cities in Turkey [76]. These cities have been ideally located for exploiting solar thermal energy as well as studying various climate patterns. The research revealed more than $3,000,000 \mathrm{~m}^{2}$ of SWHS has been constructed during 2005-2010; the installed capacity jumped to 15,497,913 $\mathrm{m}^{2}$ by 2012. The author predicted that more households afford SWHS purchases by continuing the economic growth of Turkey and the decline of the new building construction rate.

Table 5. Summary of solar water heating system research and projects in Turkey.

\begin{tabular}{|c|c|c|c|c|c|}
\hline System Type & Testing Period & System Spec. & Usages & $\begin{array}{c}\text { Max. } \\
\text { Collector/Tank } \\
\text { Reached Temp. }\end{array}$ & $\begin{array}{l}\text { Payback } \\
\text { Period }\end{array}$ \\
\hline SWHS [77] & A year & $100 \mathrm{~L}$ water tank & DHW & $55^{\circ} \mathrm{C}$ & $2.98-8.24$ years \\
\hline SWHS [78] & A year & $\begin{array}{l}3.72 \mathrm{~m}^{2} \text { collector and } \\
217 \mathrm{~L} \text { water tank }\end{array}$ & DHW & $55^{\circ} \mathrm{C}$ & - \\
\hline SWHS [79] & A year & $\begin{array}{l}2.9 \mathrm{~m}^{2} \text { collector and } \\
220 \mathrm{~L} \text { water tank }\end{array}$ & DHW & $60{ }^{\circ} \mathrm{C}$ & 5-10 years \\
\hline SWHS [80] & $\begin{array}{c}\text { A year } \\
\text { (except June-October) }\end{array}$ & $\begin{array}{l}38 \mathrm{~m}^{2} \text { SWHS and } \\
110 \mathrm{~L} \text { water tank }\end{array}$ & Space heating & $60{ }^{\circ} \mathrm{C}$ & - \\
\hline
\end{tabular}

The effect of different collector types, including copper, galvanized sheet, and selective absorber, on the techno-economic feasibility of SWHS in 129 sites across Turkey has been investigated [77]. The annual energy demand to support $100 \mathrm{~L}$ of $55^{\circ} \mathrm{C}$ hot water of a family with four residents has been estimated in the 1418.69-1975.08 kWh range. The results underlined that although the selective absorbers provide the required water heating all over Turkey, the payback period of the proposed SWHS with the galvanized collector is 2.98 to 8.24 years, which is lower than other collector types and electricity-based or liquid gas-based heaters.

Yaman and Arslan determined the optimum size of storage tanks and number of solar collectors in SWHS based on the life cycle cost (LCC) assessment [78]. The analysis has been presented for different locations in Turkey during the annual and seasonal timeframes. In this context, the effect of daily hot water demand besides its temperature, and the DHW side view on an optimum SWHS configuration have been initially explored. The SWHS consists of a flat plate solar collector, storage tank with an auxiliary conventional heater, a circulation pump, piping, and controls. The outputs illustrated that LCC reduces at least by $3.3 \%$ /year by the optimized selection. Moreover, all optimum solutions ensure at least a $40 \%$ share of solar energy, saving $40 \%$ energy and cost. The authors showed that a higher solar fraction and lower LCC can be achieved by increasing the water tank volume. Further, the investment goes up by a greater solar fraction selection, whereas the operation and energy costs have been dropped. It was finally found that the optimum number of solar collectors with $0.93 \mathrm{~m}^{2}$ surface area is five with storage tank volumes of 217 and $178.6 \mathrm{~L}$ in the summer and winter seasons, respectively.

Another optimization research on residential SWHS in Turkey has been conducted by Yilmaz [79]. In this regard, all critical parameters of the system have been simulated via System Advisor Model for a full year's performance. In addition, the overall performance of the system as well as the important characteristics of solar collectors, storage tank, and 
daily water demands have been analyzed. The results highlighted that $300 \mathrm{MW}$ annual energy can be saved in a typical residential building by configuring an optimal evacuated solar water heater. This yields a $5-22 \mathrm{~g} \mathrm{CO}_{2}$ equivalent/ $\mathrm{kWh} /$ year reduction in greenhouse gas emissions. A $12 \%$ higher annual energy saving would be achieved by implementing optimum results, and the capital system cost and the payback period would be dropped by $7.5 \%$ and 1.5 years, respectively.

A techno-environmental assessment of SWHS for space heating and DHW at the household scale has been conducted in the TSOL platform [80]. In this case, the level of DHW, space heating capacity, $\mathrm{CO}_{2}$ emissions reduction, and the use of an auxiliary conventional boiler have been assessed for two collector types. It was found that the efficiency of an evacuated tube water heater is greater than that of flat plate at all 45 stations. It was also shown that the annual generated heat of the FPC and evacuated tube solar collector is 253 and 357.4 MWh, respectively. The authors recommended the radiation level is greater in the southern regions of Turkey and the use of SWHS is more money-making.

Turkey is among the pioneer countries in the Middle East in employing renewable energy technologies such as SWHS, and government incentive plans have accelerated developing this technology across the country [75]. Although the importing costs of SWHS equipment makes these sources expensive and not viable for the residential sector, the costs can be diminished substantially by domestic generation of this technology.

\subsection{Solar Water Heating Systems in Yemen}

Yemen is a sunshiny country with about $3000 \mathrm{~h}$ of sunshine annually with average solar radiation of $2400 \mathrm{kWh} / \mathrm{m}^{2} /$ year. In this context, an average daily solar radiation of about 748 and $700 \mathrm{~W} / \mathrm{m}^{2}$ for Sanaa and Aden is reported [81,82]. Yemen is classified as tropical weather with hot weather in the most coastal, southern, and eastern regions and cold weather in the northern and middle regions. Despite the importance of renewable energy sources for Yemen, unfortunately, very limited activities are in practice.

There are several domestic solar water heaters in cities such as Sana which are not working properly compared to the electrical water heaters. The high initial costs, improper installation, and the low-cost rate per $\mathrm{kW}$ of electricity yield fewer developments of SWHS in Yemen [81]. A study presents an experimental thermosiphon SWHS which has been designed with available local materials under the meteorological conditions of Aden city. The performance of the system was considered under non-drawn off and drawn off hot water conditions. The results showed that the maximum temperature in the water tank reached $60{ }^{\circ} \mathrm{C}$ whilst the maximum efficiency would be 30-70\% during a clear day [82]. Despite the high solar potential, recent wars, recessions, and governmental problems had adverse impacts in developing SWHS technology in Yemen.

\subsection{Solar Water Heating Systems in Gulf Cooperation Council Countries}

The Gulf Cooperation Council (GCC) contains the countries around the Persian Gulf, including "Bahrain, Kuwait, Oman, Qatar, Saudi Arabia, and the United Arab Emirates". There is abundant solar potential in the GCC region and thus, the investment in the renewable energy sector increases notably, as illustrated in Figure 13. SWHS has been considered as one of the practical applications in this area and some studies and projects have been conducted in this context [14]. 


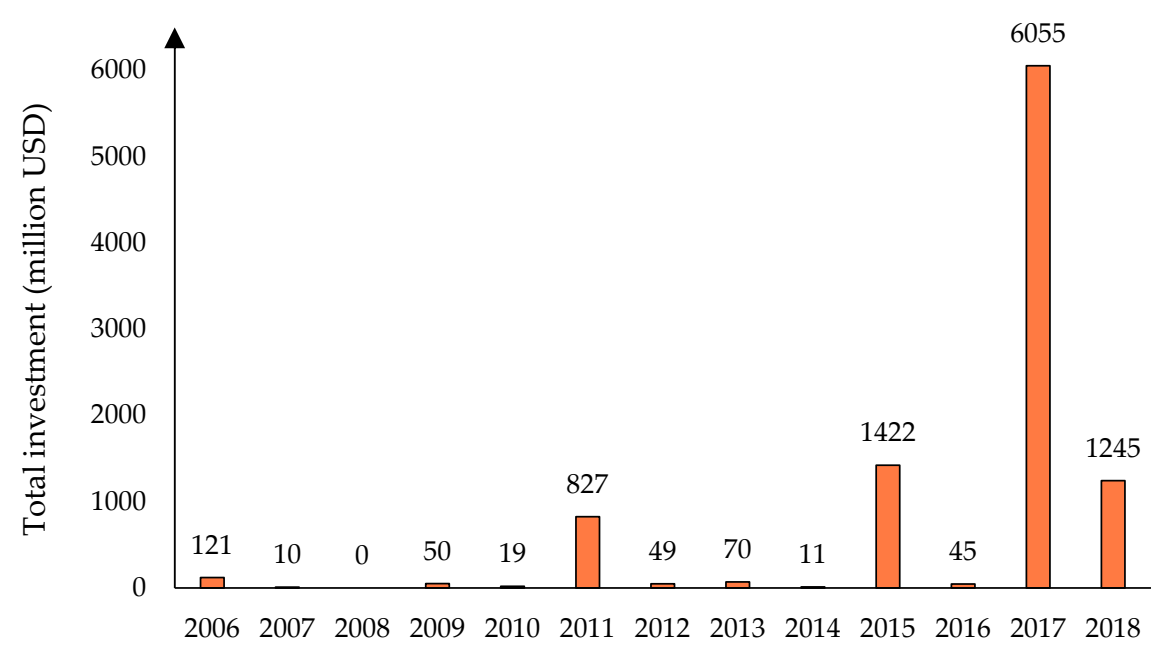

Figure 13. Annual investment of GCC in renewable energy [14].

\subsubsection{Kuwait}

Since the population in Kuwait is growing, the total energy demand has risen drastically over the past decades. The sunshine hours are considerable across the country, especially in the hot months of the summer; solar systems can be developed to effectively support the energy requirements accordingly. The average solar energy hours in Kuwait are about $9-11 \mathrm{~h} /$ day, with an average daily solar irradiance greater than $7.0 \mathrm{kWh} / \mathrm{m}^{2}$ and an annual average of $2100-2200 \mathrm{kWh} / \mathrm{m}^{2}$ [83]. While PV systems have been installed marginally in Kuwait, a few SWHS projects and studies have been conducted [84,85].

An economic feasibility assessment of a PV-solar DHW system in Kuwait has been presented [84]. In this study, the solar collectors have been replaced by PV panels in SWHS. Hence, the system comprises of PV modules which are linked to the heating elements within a storage tank. The PV modules generate electricity, which is dissipated immediately in the resistive elements, embedded in a water tank. In comparison with the traditional SWHS, this system provides several advantages, such as no piping and plumbing, no heat exchanger and no need to have antifreeze fluid in cold conditions, simple and noise-free installation, more reliability, and durable operation. However, the further installation area of the PV array and higher costs are known as the main demerits. According to PV module price and low oil price in Kuwait, the simulation results indicated that the presented PV-powered SWHS is not economically viable. Moreover, the authors inferred that establishing an incentive policy or a 50\% PV module price drop is mandatory for making PV-SWHS cost-competitive.

Ghoneim et al. explored the performance and feasibility of a designed SWHS for space heating, DHW, and cooling demands of a residential house in Kuwait [85]. The weather data, including sets of received insolation on a horizontal surface (solar radiation between 600 and $1000 \mathrm{~W} / \mathrm{m}^{2}$ ), clearness index, ambient temperature, and wind speed have been modeled in the simulations. The authors adopted a conventional FPC with transparent insulation materials due to the high costs of ETCs. The system components are similar to other SWHS, besides having an absorption chiller for the cooling demands. The results highlighted that the modified FPC affects the performance of the solar systems by reducing the optimum collector area needed (nearly equal to $32 \mathrm{~m}^{2}$ ). In addition, greater heating and cooling demands are supplied by the developed system whilst the cost of energy units of the modified FPC is $36 \%$ cheaper than the conventional fuel.

\subsubsection{Bahrain}

The Kingdom of Bahrain lies in the latitude of $26^{\circ} \mathrm{N}$ and longitude of $50.5^{\circ} \mathrm{E}$. The average solar irradiance in the country is around $2600 \mathrm{kWh} / \mathrm{m}^{2} /$ year. In the country's renewable energy action plan, a target of 5\% renewable energy by 2025 is specified to ensure a $480 \mathrm{GWh}$ /year generation of clean energy [86]. The share of the renewable source should 
be $10 \%$ by 2035 which is $1460 \mathrm{GWh}$ /year of clean energy. Nevertheless, the deployment of SWHS is still limited in Bahrain due to its high burden cost and the lower fuel price.

The performance of the solar thermosiphon water heater unit in Bahrain has been studied by Karaghouli and Alnaser [87]. The experimental system consists of a flat plate solar collector and an isolated cylindrical water storage tank, and thermocouples have been used to measure the storage tank's water temperature as well as the ambient and collector back temperature. The results illustrated the $38 \%$ average efficiency of the system with an ambient temperature between $19-25{ }^{\circ} \mathrm{C}$ and useful solar energy ranged from $6.07-7.33 \mathrm{MJ} / \mathrm{m}^{2}$. Thus, the thermal applicability can be supported markedly by the presented system.

Ghaliche et al. adopted the integrated conical solar collector water heater (ICSCWH) in which the solar flux is converted to heat efficiently [88]. The main parts of ICSCWH are a conical collector, storage vessel, and water supply system. The study presented an outdoor evaluation and mathematical calculation of an ICSCWH system to figure out thermal efficiency. It is highlighted that the highest system efficiency from the experimental and analytical data is 32.75 and $30.57 \%$, respectively. Further, the optimum useful energy of the system is 0.33 and $0.37 \mathrm{~kW}$, respectively.

\subsubsection{Oman}

The Sultanate of Oman lies between the latitude of $160-280^{\circ} \mathrm{N}$ and longitudes of $520-600^{\circ} \mathrm{E}$, which covers an area of $300,000 \mathrm{~km}^{2}$. Oman's climate is mainly humid and arid with a magnificent supply of solar energy throughout the year, i.e., the annual solar irradiance of Oman is at least $2200 \mathrm{kWh} / \mathrm{m}^{2}$ [89]. The residential sector, which consumes more than $47 \%$ of the total demand mostly for water heating, air conditioners, and cooking applications, is known as the largest consumer [90]. Although electrical power is produced mostly by natural gas in Oman, the SWHS is considered a suitable option to support DHW usage.

Various methodologies for developing energy-efficient buildings in Oman have been proposed by Al-Badi and S. N. Al-Saadi [89]. In this regard, the buildings have been designed to diminish energy consumption through natural methods. Solar energy with SWHS and PV solutions has been recommended to lessen the building's dependency on utility supply. The investigations showed that $5 \%$ of total energy consumption would be preserved by employing the SWHS instead of the conventional electrical heater. However, the SWHS could be supported by a $6 \mathrm{~kW}$ PV system in an energy-efficient building so that $58 \%$ of the generated energy can be saved in the residential buildings through the combined active and passive systems.

Most of the residential houses in Oman exploit old heating systems which can be replaced by SWHS. Thus, energy-saving, economic feasibility, and greenhouse gas emission reduction by replacing electric water heaters with SWHS in residential buildings have been studied in [91]. The authors claimed that it is possible to save $1859 \mathrm{GWh} /$ year energy by implementing SWHS in Oman. This energy would be generated by $212 \mathrm{MW}$ fossil-fuel based power stations per year, i.e., $212 \mathrm{MW}$ power plants could be de-energized. They also argued that the mentioned energy saving avoids more than 1.227 million tons/year $\mathrm{CO}_{2}$ emissions and saves more than 24.5 million USD/year in all governorates. Furthermore, the economic indicators imply that a 10 -year payback period is practically achievable. It was finally deduced that the spreading of the SWHS in Oman needs some incentive policies that motivate residents to invest in such projects.

A techno-economic assessment of a primary case study in the Seeb district has been reported [92]. Energy production, saving costs, emission reduction, economic viability, and risk level have been analyzed for a typical house with four residents in RETScreen software. The results implied that the equity payback period is 10 years, whilst a $50 \%$ grant/incentive for the initial costs of SWHS has been considered. The energy saving for Seeb was estimated at 335,431 MWh/year, which could be generated by a $38.3 \mathrm{MW}$ power plant, saving $148,590 \mathrm{t}$ /year $\mathrm{CO}_{2}$ emissions. The authors emphasized defining 
a government subsidies framework or investing half of the capital cost to facilitate the diffusion of the SWHS.

\subsubsection{Qatar}

Qatar is placed inside the sun-belt zone of the world, an area that receives plenty of solar radiation with an average of $2113 \mathrm{kWh} / \mathrm{m}^{2} /$ year. Therefore, this country aimed to produce $10 \%$ of its electricity from solar-based resources by 2018 [93]. On the other hand, the residential sector consumed around 50\% of the country's energy [94]. Since the total population grows at an average rate of $2.1 \%$, it is expected to find different solutions to satisfy the energy needs. Implementing SWHS is among the possible solutions, and several efforts have been recently performed to develop such systems.

Gowid et al. investigated the techno-economic feasibility of the net-zero energy housing (NZEH) implementation to the existing residential villas in Qatar [95]. In this context, major subsystems such as thermal insulation, solar power generation, and SWHS have been modeled precisely, and afterwards, the cost and benefits of the new house have been figured out over the 25 years. In the presented NZEH, an SWHS was considered to support the hot water demands of a typical villa to have a cost-effective and eco-friendly system when a PV system was designed to provide the required electricity. According to Qatar's conditions, FPCs are more efficient with lower costs, and using copper tubes has yielded better performance in comparison with the other materials. The results showed that an SWHS provides $300 \mathrm{~L} /$ day of hot water. Accordingly, a total saving of 190 Qatar Rials/year is achievable considering the performance of a conventional electrical heater disregarding the maintenance costs, e.g., a $2 \mathrm{~kW} /$ hour heater provides $100 \mathrm{~L}$ of hot water in $85 \mathrm{~min}$.

Although the energy price is low in Qatar, the country aims to construct solar-based power plants. The major solar thermal project in Qatar has been realized to meet hot water demands in Downtown Msheireb. In this area, $1 \mathrm{MW}$ solar collectors were installed in the buildings to guarantee a steady supply of hot water. There are some other projects with a capacity of 1.5-2 MW in residential and commercial projects, such as Lusail and ISF camp [96].

\subsubsection{United Arab Emirates}

The United Arab Emirates has substantial solar potential with average solar radiation of $2285 \mathrm{kWh} / \mathrm{m}^{2} /$ year, and an average of 10 sunshine hours per day [97]. In spite of the redundancy of solar energy in the country, the use of SWHS for domestic heating purposes is limited.

The residential energy consumption rate in the UAE is $39 \%$ which is greater than many European countries, e.g., an apartment consumes 12,000 kWh/year electricity. Hence, SWHS can be applied to reduce electricity consumption effectively in the residential sector. In this context, the potential of energy-efficient SWHS in residential buildings has been studied by Al-Saleh and Taleb [98]. The experimental tests and energy simulations have been conducted on a house with 11 occupants. A scenario was defined to monitor the energy consumption of the studied case in which the utility electricity bills have been recorded during the first year. A few modifications have been applied for the second year such as installing SWHS, employing more efficient electric heaters, and changing the hot water temperature's set point. The comparison of the electricity bills of the two consecutive years highlighted a $7 \%$ reduction in overall electricity consumption. The annual household energy consumption level had been fallen from 189 to $175.6 \mathrm{MWh}$ as well.

Aoul et al. presented efficient architects to benefit solar thermal collectors for hot water demands of several building types, including residential, schools, hospitals, offices, and factories [99]. Different design parameters have been investigated for an SWHS. The results indicate that modifying the optical elements, employing the tracking systems, and structural support lead to a higher cost and greater temperature for industrial and hospital 
applications. The payback period of the presented system is almost two years in the optimized case under the climatic conditions of Dubai and subsidized tariff rates.

The presented works in the literature highlight clearly the necessity of adopting an incentive policy for developing SWHS in Bahrain, Kuwait, Oman, Qatar, and the United Arab Emirates. Otherwise, this technology is not economically viable regarding the low energy cost.

\subsubsection{Saudi Arabia}

The Kingdom of Saudi Arabia is located in the world's sun-belt at $36.6-50^{\circ}$ E longitudes and $17.5-31^{\circ} \mathrm{N}$ latitudes with an annual average solar radiation of $2200 \mathrm{kWh} / \mathrm{m}^{2}$ [100]. Hot water demand is an important part of energy consumption in the residential sector of this country, where electric water heaters consume the majority of the energy, especially in the wintertime. Most houses in Saudi Arabia exploit electricity to heat water and $11 \%$ of the total electricity consumption belongs to the DHW applications; SWHS can be applied accordingly [101]. Furthermore, Saudi Arabia's demand for electricity has climbed by 3-15\% within the last 20 years [102]. Therefore, the development of SWHS in Saudi Arabia can effectively reduce electricity consumption, greenhouse gas emissions, and pollution. Various scholars investigated the techno-economic feasibility of SWHS for DHW in Saudi Arabia, summarized in Table 6 [103-107]. For instance, the techno-economic assessment of two different solar collectors has been presented by Abd-Ur-Rehman and Al-Sulaiman [103]. Simulations have been performed for five cities, including Jeddah (western coast), Dhahran (eastern coast), Riyadh (center), Tabuk with minimum daily solar radiation (north), and Bisha with maximum daily solar radiations (south) to cover different geographical conditions. The minimum solar fraction has been set at $50 \%$ in the presented simulations, whilst the remaining demand is provided by a backup electricity system. The results unveiled that Bisha is an attractive region for SWHS application regarding the high received solar irradiance. Moreover, the authors illustrated that the SWHS in Bisha and Jeddah achieves a 50\% solar fraction with one evacuated tube/glazed solar collector. On the contrary, the presented system requires single evacuated/two glazed solar collectors in Dhahran and Riyadh to accomplish this goal. In Tabuk with the lowest received solar isolation, the SWHS should be equipped with at least two evacuated/three glazed solar collectors to obtain the required solar fraction. It was also revealed that the evacuated collector in all cities results in a higher solar fraction, greater energy saving, and more greenhouse gas reduction. Financial assessments concluded that Bisha has the most economic efficiency with a reasonable payback period for both collector types, while Tabuk is not economically viable owing to its low solar radiation potential.

Table 6. Summary of solar water heating system research and projects in Saudi Arabia.

\begin{tabular}{|c|c|c|c|c|c|}
\hline System Type & Location & $\begin{array}{l}\text { Testing } \\
\text { Period }\end{array}$ & Building Type & System Spec. & $\begin{array}{l}\text { Payback } \\
\text { Period }\end{array}$ \\
\hline $\begin{array}{c}\text { Evacuate tube collector } \\
\text { SWHS [104] }\end{array}$ & Seven cities & Two years & Residential house & $\begin{array}{l}2.85 \mathrm{~m}^{2} \text { collector, seven occupant } \\
\text { and } 54 \mathrm{~L} / \text { capita daily hot water } \\
\text { demand }\end{array}$ & $3.4-3.9$ years \\
\hline FPC SWHS [105] & Seven cities & Two years & Residential house & $\begin{array}{l}\text { Seven occupant and } 54 \mathrm{~L} / \text { capita } \\
\text { daily hot water demand }\end{array}$ & $7.25-8.35$ years \\
\hline $\begin{array}{c}\text { Evacuate tube collector } \\
\text { SWHS [106] }\end{array}$ & Five cities & A year & Hospital & $\begin{array}{l}200 \text { bedrooms, } 31,500 \mathrm{~L} \text { daily hot } \\
\text { water usage, } 21 \text { collectors }\end{array}$ & 8.9 years \\
\hline Glazed FPC SWHS [106] & Five cities & A year & Hospital & $\begin{array}{l}200 \text { bedrooms, } 31,500 \mathrm{~L} \text { daily hot } \\
\text { water usage, and } 24 \text { collectors }\end{array}$ & 7 years \\
\hline
\end{tabular}

The performance of the evacuated SWHS in residential buildings of six locations, including Najran, Tabuk, Dhahran, Jeddah, Qassim, and Riyadh, have been studied in [104]. The techno-economic feasibility of SWHS, including ETC with heat pipes, has been explored in the RETScreen platform. The outputs demonstrated that the maximum and minimum obtained solar fractions were $67 \%$ and $58 \%$ in Najran and Dhahran, respectively. The 
annual delivered thermal energy by SWHS in different cities is between 4.0-4.5 MWh for Dhahran and Najran as the lowest and highest sets, respectively. The authors claimed that the annual electrical energy received from the utility drops from 7.3 MWh to 2.4-3 MWh when the presented SWHS has been exploited. Meanwhile, the $\mathrm{CO}_{2}$ reduction would also be between 3.7-4.2 t/year. The economic indices highlighted that Najran, with 3.4 years payback time and 162 USD annual life cycle savings, is the best location among the six cities. Finally, the authors concluded that Saudi Arabia, with a payback time of fewer than 4 years, has a high potential for applying evacuated tube SWHS with heat pipe.

Al-Sulaiman and Almahmoud investigated the techno-economic feasibility of two SWHSs for a hospital with 200 beds in Tabuk, Dhahran, Riyadh, Jeddah, and Najran [105]. Since the desired temperature for hot water in hospitals is between $50-60{ }^{\circ} \mathrm{C}$, the glazed flat plate and ETCs have been proposed. The results illustrated that the solar fraction in Tabuk varies from $49 \%$ to 55\% whilst Najran and Dhahran have the highest and lowest solar fraction, respectively. In addition, the average energy saving would be at most $250 \mathrm{MWh}$ /year in Tabuk and $200 \mathrm{MWh}$ /year in Jeddah as the minimum level. The $\mathrm{CO}_{2}$ emissions reduce by at most $200 \mathrm{t} /$ year in Tabuk and Najran. The economical assessment remarked that, for instance, the payback period of ETCs in Tabuk and Najran is just under 9 years. This parameter is less than 7 years for the same SWHS with glazed FPC. Moreover, the analysis confirmed the advantage of the glazed FPC over the evacuated tubes, e.g., it has a shorter payback period and longer annual life cycle saving.

A comprehensive assessment of SWHS in ten different cities of Saudi Arabia has been reported [107]. The simulation results indicated that Nejran, Bisha, and Madina are the best sites for SWHS construction while Sulayyil has the minimum attraction from a techno-economic standpoint. Similar to [103], it was shown that the efficiency of evacuated SWHS collectors is higher than the glaze collector's one in all ten cities. According to the economy of scale, the authors stated that a higher number of residents reduces the system cost per unit; a lower pay pack time and a greater benefit to cost ratio would be deduced accordingly.

There is tremendous potential for developing SWHS in the GCC countries such as Saudi Arabia. Although most of the region's countries have started investing in this technology within recent years, low fuel prices and high initial costs for the residential sector are the main barriers. According to conducted research and the weather conditions of the GCC countries, most incentive programs and government policies are around developing PV plants, and solar water systems are mostly used in industrial zones and water desalination sectors.

\section{Conclusions and Recommendations for Future Improvements}

The Middle East is an area with plenty solar potential and fossil-fuel resources. The energy of most countries is currently supported by fossil fuels, leading to a low energy price and a sharp rise in energy demand. Thus, the development of solar-based technologies confronts economic challenges. Although these sources operate with high yield due to the great solar potential of the region, the low energy price limits the investment of the residents in the solar industry.

This paper reviewed recent research about the techno-economic assessment of SWHS in the Middle East and highlighted the current position, progress, barriers, and challenges of expanding this technology. It has been found that:

- $\quad$ There has been a moderate development through SWHS applications among most countries within the last few decades. The low energy cost supplied by rich fossil-fuel resources is the main reason for this eminent low installation rate (Table 7) [108].

- Lebanon and Turkey are the pioneer countries in the region, developing SWHS in the local and industrial markets at a steady pace. In addition to the high energy cost, these governments have set incentive programs for developing SWHS.

- There are a few countries with supportive policies for constructing renewable energies with low priority to SWHS. For instance, Iran has traced a roadmap to expand 
renewable energies in the country through setting a dynamic feed-in tariff (FiT) plan for purchasing the total generated energy of different renewable energies at a guaranteed price for twenty years. Since the country suffers from the electricity shortage in midsummer, SWHS has no priority in this country [109].

Table 7. Household electricity price and supportive policies of SWHS by counties [108].

\begin{tabular}{ccc}
\hline Country & Electricity Cost (USD/kWh) & Grant Policies for SWHS? \\
\hline Iran & 0.005 & no \\
\hline Iraq & 0.024 & no \\
\hline Egypt & 0.045 & no \\
\hline Jordan & 0.100 & no \\
\hline Lebanon & 0.077 & yes \\
\hline Turkey & 0.080 & yes \\
\hline Kuwait & 0.030 & no \\
\hline Bahrain & 0.048 & no \\
\hline Oman & 0.026 & no \\
\hline Qatar & 0.032 & no \\
\hline UAE & 0.081 & no \\
\hline Saudi Arabia & 0.048 & no \\
\hline
\end{tabular}

- The weather conditions of the countries have a substantial effect on developing SWHS. For example, most of the GCC countries are located in arid areas with a hot and humid climate, in which using hot water for space heating or even bathing is considered unnecessary. Accordingly, SWHS technology would be economically infeasible in GCC countries with low energy costs.

It is concluded that although there is a public willingness to use SWHS in most countries, there are some obstacles that must be eliminated to promote this technology in the region, including:

- Low energy price of electricity and liquid gas due to the high subsidies of fossil-fuel resources. Lebanon and Turkey are two instances with low fossil fuel reservoirs and high energy costs. In these countries, the SWHS is hence employed widely to support domestic usages inexpensively.

- Inadequate legislation and policy frameworks by governments. In order to boost the attractiveness of investment in SWHS, the government should legalize incentive policies. Otherwise, the SWHS with high burden costs is not competitive in comparison with the inexpensive fossil-fuel-based energy. Similar policies have been realized for grid-tied PV systems in the region, e.g., this technology has been developed sharply in Iran under a new dynamic FiT framework since 2014 [109].

- Lack of public awareness for using solar energy systems and their advantages. Some countries, such as Yemen, Palestine, and Syria, which have been involved in wars recently, have not been able to expand renewable energy technologies, and society needs to be aware of SWHS advantages to be encouraged for exploiting them. However, there were some efforts to use and implement solar systems in the war-torn areas [110].

- High capital costs of SWHS compared to the conventional water heating systems. Most countries in the Middle East are faced with high initial costs of SWHS. In this case, the governments must play the main role to alleviate the SWHS's costs, e.g., by reducing the import tariff, low-interest rate loans, and incentive frameworks.

- Lack of research and development capabilities. The Middle Eastern research centers and universities can join worldwide programs to share their experiences in terms of 
expanding renewable energy technologies and widen their knowledge to apply the newest achievements in the region, i.e., using PCM versus SWHS in the buildings to have a zero net energy building is a new approach in most European countries to store the produced heat for more time in the house [111].

There could be some ways for the aforementioned problems which can accelerate the SWHS market in the Middle East. Some of the possible solutions are:

- Establishing visions and missions' goals for renewable energy systems by governments to move toward it. It is necessary to define what the ultimate goals are in the long term, and what are the short-term goals?

- Knowledge exchange programs between governments and research centers of the Middle East to facilitate SWHS expansion.

- Attending international collaboration to develop the SWHS market and accelerate its trend among the residential and industrial zones.

- Raising public awareness by conducting social campaigns, incentive programs, and create awareness in academic centers for developing research in solar water heating systems.

- Establishing incentive policies such as FiT, installing subsidies, and financial rewards for customers who install SWHS by calculating the total saved energy for each user with implementing such a system. These policies should be legalized regarding the economic condition and solar potential of the region/country.

Beyond this, there are a variety of parameters that can be considered for future improvements. For example, heat storing methods, zero-net energy buildings, isolation mechanisms, and proper installation types for different climate conditions are some of the other important factors to increase the efficiency of SWHS.

As previously mentioned, population growth and future energy demands in the Middle East are two important factors which must be considered by governments as soon as possible. By removing the mentioned barriers and challenges toward developing SWHS, it is possible to have a bright vision to reduce the environmental issues due to the $\mathrm{CO}_{2}$ emissions and other toxic gasses. There is also this hope to descend social concerns for future energy scarcity in the Middle East by expanding different renewable energy systems such as SWHS, PV, and hybrid systems.

Author Contributions: Conceptualization, M.D. and C.F.P.; methodology, M.D. and R.B.-J.; validation, M.D., C.F.P., R.B.-J. and E.R.; investigation, M.D. and R.B.-J.; resources, M.D., R.B.-J. and E.R.; writing-original draft preparation, M.D.; writing—review and editing, R.B.-J. and E.R.; visualization, M.D. and C.F.P.; supervision, R.B.-J. All authors have read and agreed to the published version of the manuscript.

Funding: This research received no external funding.

Institutional Review Board Statement: Not applicable.

Informed Consent Statement: Not applicable.

Data Availability Statement: Not applicable.

Conflicts of Interest: The authors declare no conflict of interest. 


\section{Nomenclature}

$\begin{array}{llll}\text { Acronyms } & & \text { NZEH } & \text { Net-zero energy housing } \\ \text { COP } & \text { Coefficient of performance } & \text { Units } & \\ \text { DHW } & \text { Domestic hot water } & \mathrm{d} & \text { Day } \\ \text { DSHWST } & \text { Domestic solar hot water storage tank } & \mathrm{GWh} & \text { Gigawatt-hour } \\ \text { FiT } & \text { Feed-in tariff } & \mathrm{h} & \text { Hour } \\ \text { ETC } & \text { Evacuated tube collector } & \mathrm{kg} & \text { kilogram } \\ \text { FPC } & \text { Flat plate collector } & \mathrm{ktoe} & \text { kiloton of oil equivalent } \\ \text { GGS } & \text { Gas geyser system } & \mathrm{kWh} & \text { kiloWatt-hour } \\ \text { HWHS } & \text { Hybrid water heating system } & \mathrm{L} & \text { Liter } \\ \text { ICS } & \text { Internal collector storage } & \mathrm{m} & \text { Meter } \\ \text { LCC } & \text { Life cycle cost } & \mathrm{min} & \text { Minute } \\ \text { PCM } & \text { Phase change material } & \mathrm{MJ} & \text { Megajoule } \\ \text { PV } & \text { Photovoltaic } & \mathrm{mm} & \text { Millimeter } \\ \text { P-FPC } & \text { Parallel flat plate collector } & \mathrm{MWh} & \text { Megawatt-hour } \\ \text { Qhw } & \text { Quantity of hot water } & \mathrm{m} & \text { Square meter } \\ \text { SAHP } & \text { Solar-assisted heating pump } & \mathrm{m} & \text { Cubic meter } \\ \text { SWHS } & \text { Solar water heating system } & \mathrm{s} & \text { Second } \\ \text { S-FPC } & \text { Series flat plate collector } & \mathrm{t} & \text { Ton } \\ \text { Vhw } & \text { Volume of hot water } & \mathrm{W}_{\mathrm{p}} & \text { Watt peak } \\ \text { GCC } & \text { Gulf Cooperation Council } & { }^{\circ} \mathrm{C} & \text { Degree Celsius } \\ \text { ICSCWH } & \text { Integrated conical solar collector water heater } & & \end{array}$

\section{References}

1. Sadhishkumar, S.; Balusamy, T. Performance improvement in solar water heating systems-A review. Renew. Sustain. Energy Rev. 2014, 37, 191-198. [CrossRef]

2. Tian, Y.; Zhao, C.Y. A review of solar collectors and thermal energy storage in solar thermal applications. Appl. Energy 2013, 104, 538-553. [CrossRef]

3. da Silva, H.B.; Uturbey, W.; Lopes, B.M. Market diffusion of household PV systems: Insights using the Bass model and solar water heaters market data. Energy Sustain. Dev. 2020, 55, 210-220. [CrossRef]

4. Singh, A.; Anand, A.; Shukla, A.; Sharma, A. Environmental, technical and financial feasibility study of domestic solar water heating system in India. Sustain. Energy Technol. Assess. 2021, 43, 100965.

5. Huang, J.; Fan, J.; Furbo, S.; Li, Q. A policy study on the mandatory installation of solar water heating systems-Lessons from the experience in China. Sol. Energy 2020, 206, 614-627. [CrossRef]

6. Shafieian, A.; Khiadani, M. Integration of heat pipe solar water heating systems with different residential households: An energy, environmental, and economic evaluation. Case Stud. Therm. Eng. 2020, 21, 100662. [CrossRef]

7. Giglio, T.; Lamberts, R. Savings related to solar water heating system: A case study of low-income families in Brazil. Energy Build. 2016, 130, 434-442. [CrossRef]

8. Chang, K.-C.; Lin, W.-M.; Chung, K.-M. Sustainable development for solar heating systems in Taiwan. Sustainability 2015, 7, 1970-1984. [CrossRef]

9. Jahangiri, M.; Alidadi Shamsabadi, A.; Saghaei, H. Comprehensive evaluation of using solar water heater on a household scale in Canada. J. Renew. Energy Environ. 2018, 5, 35-42.

10. Şerban, A.; Bărbuţă-Mişu, N.; Ciucescu, N.; Paraschiv, S.; Paraschiv, S. Economic and environmental analysis of investing in solar water heating systems. Sustainability 2016, 8, 1286. [CrossRef]

11. Comparison of Solar and Heat Pump Water Heaters in New Zealand; Report Prepared for the Parliamentary Commissioner for the Environment. 2011. Available online: https://www.pce.parliament.nz/media/1245/comparison-of-solar-and-heat-pumpwater-heaters-in-new-zealand.pdf (accessed on 1 August 2021).

12. Singh, S.; Anand, A.; Shukla, A.; Sharma, A. Technical, financial, and environmental feasibility of solar water heater for residential, commercial, and industrial application: A theoretical approach. Mater. Sci. Energy Technol. 2020, 3, 648-671. [CrossRef]

13. Bahrampour, H.; Beheshti Marnani, A.K.; Askari, M.B.; Bahrampour, M.R. Evaluation of renewable energies production potential in the Middle East: Confronting the world's energy crisis. Front. Energy 2017, 14, 42-56. [CrossRef]

14. Mas'ud, A.; Wirba, A.; Alshammari, S.; Muhammad-Sukki, F.; Abdullahi, M.; Albarracín, R.; Hoq, M. Solar energy potentials and benefits in the Gulf Cooperation Council countries: A review of substantial issues. Energies 2018, 11, 372. [CrossRef]

15. Nematollahi, O.; Hoghooghi, H.; Rasti, M.; Sedaghat, A. Energy demands and renewable energy resources in the Middle East. Renew. Sustain. Energy Rev. 2016, 54,1172-1181. [CrossRef]

16. Bayomi, N.; Fernandez, J.E. Towards sustainable energy trends in the Middle East: A study of four major emitters. Energies 2019, 12, 1615. [CrossRef] 
17. Raisul Islam, M.; Sumathy, K.; Ullah Khan, S. Solar water heating systems and their market trends. Renew. Sustain. Energy Rev. 2013, 17, 1-25. [CrossRef]

18. Taher, B.M.A.; Benseddik, Z.; Afass, A.; Smouh, S.; Ahachad, M.; Mahdaoui, M. Energy life cycle cost analysis of various solar water heating systems under Middle East and North Africa region. Case Stud. Therm. Eng. 2021, 27, 101262. [CrossRef]

19. Taher, B.M.A.; Al Jamar, A.; Akzoun, F.; Ahachad, M.; Mahdaoui, M. Energy Study of different solar water heating systems in MENA region. In Proceedings of the International Conference on Advanced Intelligent Systems for Sustain Development, Tangier, Morocco, 8-11 July 2019.

20. Edalati, S.M.; Ameri, M.; Iranmanesh, M.; Sadeghi, Z. Solar photovoltaic power plants in five top oil-producing countries in Middle East: A case study in Iran. Renew. Sustain. Energy Rev. 2017, 69, 1271-1280. [CrossRef]

21. Hadjipanayi, M.; Koumparou, I.; Philippou, N.; Paraskeva, V.; Phinikarides, A.; Makrides, G.; Efthymiou, V.; Georghiou, G.E. Prospects of photovoltaics in southern European, Mediterranean and Middle East regions. Renew. Energy 2016, 92, 58-74. [CrossRef]

22. Bakhshi-Jafarabadi, R.; Sadeh, J.; Dehghan, M. Economic evaluation of commercial grid-connected photovoltaic systems in the Middle East based on experimental data: A case study in Iran. Sustain. Energy Technol. Assess. 2020, 37, 100581. [CrossRef]

23. Shukla, R.; Sumathy, K.; Erickson, P.; Gong, J. Recent advances in the solar water heating systems: A review. Renew. Sustain. Energy Rev. 2013, 19, 173-190. [CrossRef]

24. Ogueke, N.V.; Anyanwu, E.E.; Ekechukwu, O.V. A review of solar water heating systems. J. Renew. Sustain. Energy 2009, 1, 043106 [CrossRef]

25. Jamar, A.; Majid, Z.A.A.; Azmi, W.H.; Norhafana, M.; Razak, A.A. A review of water heating system for solar energy applications. Int. Commun. Heat Mass Transf. 2016, 76, 178-187. [CrossRef]

26. Lee, D.W.; Sharma, A. Thermal performances of the active and passive water heating systems based on annual operation. Sol. Energy 2007, 81, 207-215. [CrossRef]

27. Fantozzi, F.; Filipeschi, S.; Mameli, M.; Nesi, S.; Cillari, G.; Mantelli, M.B.H.; Milanez, F.H. An innovative enhanced wall to reduce the energy demand in buildings. J. Phys. Conf. Ser. 2017, 796, 012043. [CrossRef]

28. Wang, W.; Tian, Z.; Ding, Y. Investigation on the influencing factors of energy consumption and thermal comfort for a passive solar house with water thermal storage wall. Energy Build. 2013, 64, 218-223. [CrossRef]

29. Growth Trend of Energy Use vs. $\mathrm{CO}_{2}$ Emissions in the Middle East. Available online: www.data.worldbank.org (accessed on 1 August 2021).

30. Solar Resource Maps and GIS Data of Middle East and North Africa. Available online: www.solargis.com/maps-and-gis-data/ download (accessed on 1 August 2021).

31. Sabry, M.; Nahas, M.; Al-Lehyani, S. Simulation of a standalone, portable steam generator driven by a solar concentrator. Energies 2015, 8, 3867-3881. [CrossRef]

32. Average Monthly Temperature of the Middle Eastern Countries. Available online: www.average-weather.com/en (accessed on 1 August 2021).

33. Khorasanizadeh, H.; Sepehrnia, M. Solar exergy evaluation and empirical model establishment; case study: Iran. Heliyon 2020, 6, e05638. [CrossRef] [PubMed]

34. Hafeznia, H.; Pourfayaz, F.; Maleki, A. An assessment of Iran's natural gas potential for transition toward low-carbon economy. Renew. Sustain. Energy Rev. 2020, 79, 71-81. [CrossRef]

35. Baneshi, M.; Bahreini, S.A. Impacts of hot water consumption pattern on optimum sizing and techno-economic aspects of residential hybrid solar water heating systems. Sustain. Energy Technol. Assess. 2018, 30, 139-149. [CrossRef]

36. Karimi, M.S.; Fazelpour, F.; Rosen, M.A.; Shams, M. Comparative study of solar-powered underfloor heating system performance in distinctive climates. Renew. Energy 2019, 130, 524-535. [CrossRef]

37. Rezania, A.; Taherian, H.; Ganji, D.D. Experimental investigation of a natural circulation solar domestic water heater performance under standard consumption rate. Int. J. Green Energy 2012, 9, 322-334. [CrossRef]

38. Hematian, A.; Ajabshirchi, Y.; Ranjbar, S.F.; Taki, M. An experimental analysis of a solar-assisted heat pump (SAHP) system for heating a semisolar greenhouse. Energy Sources Part A Recovery Util. Environ. Eff. 2019, 43, 1724-1744. [CrossRef]

39. Shaddel, M.; Shokouhian, M. Feasibility of solar thermal collectors usage in dwelling apartments in Mashhad, the second megacity of Iran. Renew. Sustain. Energy Rev. 2014, 39, 1200-1207. [CrossRef]

40. Hoseini, S.A.; Mostafaeipour, A.; Arabnia, H.R.; Alavi, O.; Shahmiri, S. An economical approach for using solar water heaters in Mashhad, Iran. In Proceedings of the Conference on Industrial Engineering and Operations Management, Rabat, Morocco, 11-13 April 2017.

41. Qolipour, M.; Zarezade, M.; Rezaei, M.; Golmohammadi, A.M.; Hadian, H.; Soltani, M. Identifying the effective factors for implementing solar water heaters (SWH) for Yazd, Iran. In Proceedings of the Conference on Industrial Engineering and Operations Management, Bandung, Indonesia, 6-8 March 2018.

42. Moghadam, B.T. Economic analysis and determination of solar contribution of solar water heaters in different parts of Iran. J. Eng. Res. 2019, 3, 107-114.

43. Beygzadeh, V.; Khalil Arya, S.; Mirzaee, I.; Miri, G. Thermodynamic analysis of a novel solar water heating system during low sun radiation in Iran. Energy Equip. Sys. 2018, 6, 317-327. 
44. Sadati, S.; Edwards, R. Incorporating solar energy sources in low energy buildings in two major cities in Iran. Energy Procedia 2019, 156, 85-89. [CrossRef]

45. Solaymani, S. A review on energy and renewable energy policies in Iran. Sustainability 2021, 13, 7328. [CrossRef]

46. Al-Kayiem, H.; Mohammad, S. Potential of renewable energy resources with an emphasis on solar power in Iraq: An Outlook. Resources 2019, 8, 42. [CrossRef]

47. Alibage, A.A. Assessing photovoltaic solar technologies as a solution for the problem of power shortage in Iraq. In Proceedings of the Portland Int. Conference on Management of Engineering and Technology (PICMET), Portland, OR, USA, $19-23$ August 2018.

48. Al-Sudany Naseer, K.; Al-Sa'ady Ahmed, F.; Shneishil, A.H. System sizing of solar water heating system in Iraq. In Ministry of Higher Education and Scientific Research-University of Technology, Energy and Renew; Energies Technologies Center: Iraq, Baghdad, 2013.

49. Al-Shamkhee, D.M.; Alghurabe, M.J.; Alsahlani, A. Experimental study of the performance of a flat plate solar water heater 4th Scientific Int. In Proceedings of the Conference Najaf (SICN), Najaf, Iraq, 29-30 April 2019.

50. Al-Madhhachi, H.S.; Ajeena, A.M.; Al-Bughaebi, N.A. Dynamic simulation and energy analysis of forced circulation solar thermal system in two various climate cities in Iraq. AIMS Energy 2021, 9, 138-149. [CrossRef]

51. Abukhanafer, G.; Karrabi, M.; Al-Fatlawi, A.W.; Mohammed, H. Application and assessment of a heated water system by solar Energy. In Proceedings of the 4th International Conference on Applied Research in Agriculture Science, Tehran, Iran, 25 November 2016.

52. Hashim, W.M.; Shomran, A.T.; Jurmut, H.A.; Gaaz, T.S.; Kadhum, A.A.H.; Al-Amiery, A.A. Case study on solar water heating for flat plate collector. Case Stud. Therm. Eng. 2018, 12, 666-671. [CrossRef]

53. Mohammed, M.N.; Alghoul, M.A.; Abulqasem, K.; Mustafa, A.; Glaisa, K.; Ooshaksaraei, P.; Yahya, M.; Zaharim, A.; Sopian, K. TRNSYS simulation of solar water heating system in Iraq. In Proceedings of the 4th WSEAS Conference on Energy and Development-Environment-Biomedicine, Stevens Point, WI, USA, 14-16 July 2011.

54. Mohammad, A.T. Design and analysis of solar space heating system in Iraq. Int. J. Therm. Environ. Eng. 2017, 15, 51-56.

55. Patlitzianas, K.D. Solar energy in Egypt: Significant business opportunities. Renew. Energy 2011, 36, 2305-2311. [CrossRef]

56. Ghoneim, A.A.; Fisch, N.; Ammar, A.S.A.; Hahne, E. Design of a solar water heating system for Alexandria, Egypt. Renew. Energy 1993, 3, 577-583. [CrossRef]

57. Elhelw, M. Analysis of energy management for heating, ventilating and air-conditioning systems. Alex. Eng. J. 2016, 55, 811-818. [CrossRef]

58. Kalogirou, S. Thermal performance, economic and environmental life cycle analysis of thermosiphon solar water heaters. Sol. Energy 2009, 83, 39-48. [CrossRef]

59. Atia, D.M.; Fahmy, F.H.; Ahmed, N.M.; Dorrah, H.T. Optimal sizing of a solar water heating system based on a genetic algorithm for an aquaculture system. Math. Comput. Model. 2012, 55, 1436-1449. [CrossRef]

60. Mokhtar Farrag, N.; Mahmoud, A. Activate application of solar water heating in residential buildings Cairo-Egypt. ARPN J. Eng. Appl. Sci. 2016, 11, 1698-1716.

61. Renewable Energy Outlook: Egypt; International Renewable Energy Agency IRENA: Abu Dhabi, UAE, 2018.

62. Hammad, M.; Ebaid, M.S.Y.; Al-Hyaria, L. Green building design solution for a kindergarten in Amman. Energy Build. 2014, 76, 524-537. [CrossRef]

63. Abu-Rumman, G.; Khdair, A.I.; Khdair, S.I. Current status and future investment potential in renewable energy in Jordan: An overview. Heliyon 2020, 6, e03346. [CrossRef]

64. Shariah, A.; Shalabi, B. Optimal design for a thermosyphon solar water heater. Renew. Energy 1997, 11, 351-361. [CrossRef]

65. Mohsen, M.S.; Akash, B.A. On integrated solar water heating system. Int. Commun. Heat Mass Transf. 2002, 29, 135-140. [CrossRef]

66. Mohsen, M.S.; Akash, B.A. Evaluation of domestic solar water heating system in Jordan using analytic hierarchy process. Energy Convers. Manag. 1997, 38, 1815-1822. [CrossRef]

67. Aboushi, A.; Raed, A. Heating indoor swimming pool using solar energy with evacuated collectors. In Proceedings of the Conference on Advances in Environment Research, Jeju Island, Korea, 29-30 July 2015.

68. Kablan, M. Techno-economic analysis of the Jordanian solar water heating system. Energy 2004, 29, 1069-1079. [CrossRef]

69. Eslami, H.; Najem, S.; Ghanem, D.A.; Ahmad, A. The potential of urban distributed solar energy in transition economies: The case of Beirut city. J. Environ. Manag. 2021, 285, 112121. [CrossRef] [PubMed]

70. Houri, A.; Salloum, H.; Ali, A.; Razik, A.A.; Houri, L. Assessment of Energy and Financial Performance of a Solar Hot Water System in a Single Family Dwelling: Case Study from Marjeyoun-South Lebanon; LCEC-The Lebanese Center for Energy Conservation: Beirut, Lebanon, 2009.

71. Ruble, I.; El Khoury, P. Lebanon's market for domestic solar water heaters: Achievements and barriers. Energy Sustain. Dev. 2013, 17, 54-61. [CrossRef]

72. Updated Policy Paper for the Electricity Sector, Ministry of Energy and Water 2019. Available online: www.energyandwater.gov. lb/mediafiles/articles/doc-100515-2019_05_21_04_27_25.pdf (accessed on 1 August 2021).

73. Beih, O.; Abou Chakra, S. Phase change material in a domestic solar hot water storage tank of the Lebanese market. In Proceedings of the 4th Int. Conference on Renew. Energies for Developing Countries (REDEC), Beirut, Lebanon, 1-2 November 2018.

74. Houri, A. Solar water heating in Lebanon: Current status and future prospects. Renew. Energy 2006, 31, 663-675. [CrossRef] 
75. Özgül, S.; Koçar, G.; Eryaşar, A. The progress, challenges, and opportunities of renewable energy cooperatives in Turkey. Energy Sustain. Dev. 2020, 59, 107-119. [CrossRef]

76. Benli, H. Potential application of solar water heaters for hot water production in Turkey. Renew. Sustain. Energy Rev. 2016, 54, 99-109. [CrossRef]

77. Ertekin, C.; Kulcu, R.; Evrendilek, F. Techno-economic analysis of solar water heating systems in Turkey. Sensors 2008, 8, 1252-1277. [CrossRef] [PubMed]

78. Yaman, K.; Arslan, G. Modeling, simulation, and optimization of a solar water heating system in different climate regions. J. Renew. Sustain. Energy 2018, 10, 023703. [CrossRef]

79. Yllmaz, İ.H. Residential use of solar water heating in Turkey: A novel thermo-economic optimization for energy savings, cost benefit and ecology. J. Clean. Prod. 2018, 204, 511-524. [CrossRef]

80. Siampour, L.; Vahdatpour, S.; Jahangiri, M.; Mostafaeipour, A.; Goli, A.; Shamsabadi, A.A.; Atabani, A. Techno-enviro assessment and ranking of Turkey for use of home-scale solar water heaters. Sustain. Energy Technol. Assess. 2021, 43, 100948.

81. Bin Gadhi, S.M.; Mukbel, M.A. A review of renewable energy activities in Yemen. Renew. Energy 1998, 14, 459-465. [CrossRef]

82. Abdull Aziz, G.M.; Mukbel, M.A. Thermal performance of solar water heater system in Yemen. Renew. Energy 1994, 4, 241-247. [CrossRef]

83. Al Otaibi, A.; Al Jandal, S. Solar photovoltaic power in the state of Kuwait. In Proceedings of the 37th IEEE Photovoltaic Specialists Conference, Seattle, DC, USA, 19-24 June 2011.

84. Muhaisen, N.A.N.; Ahmed, M.M.; Khan, S.; Habaebi, M.H.; Ahmed, N.A.; Arshad, A. Development of renewable energy potential in Kuwait. In Proceedings of the IEEE Student Conference on Research and Development, Kuala Lumpur, Malaysia, 13-14 December 2016.

85. Ghoneim, A.A.; Al-Hasan, A.Y.; Abdullah, A.H. Economic analysis of photovoltaic-powered solar domestic hot water systems in Kuwait. Renew. Energy 2002, 25, 81-100. [CrossRef]

86. Haji, S.; Durazi, A.; Al-Alawi, Y. Feed-in tariff structure development for photovoltaic electricity and the associated benefits for the Kingdom of Bahrain. Int. J. Sustain. Energy 2017, 37, 479-497. [CrossRef]

87. Karaghouli, A.; Alnaser, W. Experimental study on thermosyphon solar water heater in Bahrain. Renew. Energy 2001, 24, 389-396. [CrossRef]

88. Gaaliche, N.; Ayhan, T.; Fathallah, R. An investigation of the performance of a conical solar water heater in the Kingdom of Bahrain. E3S Web Conf. 2017, 23, 05002. [CrossRef]

89. Al-Badi, A.H.; Al-Saadi, S.N. Toward energy-efficient buildings in Oman. Int. J. Sustain. Energy 2019, 39, 412-433. [CrossRef]

90. Al-Badi, A.; Malik, A.; Al-Areimi, K.; Al-Mamari, A. Power sector of Oman-today and tomorrow. Renew. Sustain. Energy Rev. 2009, 13, 2192-2196. [CrossRef]

91. Al-Badi, A.H.; Albadi, M.H. Domestic solar water heating system in Oman: Current status and future prospects. Renew. Sustain. Energy Rev. 2012, 16, 5727-5731. [CrossRef]

92. Gastli, A.; Charabi, Y. Solar water heating initiative in Oman energy saving and carbon credits. Renew. Sustain. Energy Rev. 2011, 15, 1851-1856. [CrossRef]

93. Bachour, D.; Perez-Astudillo, D. Ground-measurement GHI Map for Qatar. Energy Procedia 2014, 49, 2297-2302. [CrossRef]

94. Meier, A.; Darwish, M.; Sabeeh, S. Complexities of saving energy in Qatar. In Proceedings of the ECEEE 2013 Summer Study, Stockholm, Sweden, 3-8 June 2013.

95. Gowid, S.; Musharavati, F.; Hamouda, A. Cost benefit analysis of a net-zero energy housing in Qatar. J. Clean Energy Technol. 2019, 7,36-41. [CrossRef]

96. Elbeh, M.B.; Sleiti, A.K. Analysis and optimization of concentrated solar power plant for application in arid climate. Energy Sci. Eng. 2021, 9, 784-797. [CrossRef]

97. Mokri, A.; Aal Ali, M.; Emziane, M. Solar energy in the United Arab Emirates: A review. Renew. Sustain. Energy Rev. 2013, 28, 340-375. [CrossRef]

98. Al-Saleh, Y.; Taleb, H. Applying energy-efficient water heating practices on the residential buildings of the United Arab Emirates. Int. J. Environ. Sustain. 2014, 9, 35-51. [CrossRef]

99. Aoul, K.T.; Hasan, A.; Riaz, H. Solar water heating systems for different buildings under a hot climate; parametric optimization and economic analysis. Sustain. Build. 2018, 3, 3. [CrossRef]

100. Mujabar, S.; Chintaginjala Venkateswara, R. Empirical models for estimating the global solar radiation of Jubail industrial city, the Kingdom of Saudi Arabia. SN Appl. Sci. 2021, 3, 95. [CrossRef]

101. Stevanović, S.; Pucar, M. Financial measures Serbia should offer for solar water heating systems. Energy Build. 2012, 54, 519-526. [CrossRef]

102. Amran, Y.H.A.; Amran, Y.H.M.; Alyousef, H.; Alabduljabbar, H. Renewable and sustainable energy production in Saudi Arabia according to Saudi Vision 2030; Current status and future prospects. J. Clean. Prod. 2020, 247, 119602. [CrossRef]

103. Abd-Ur-Rehman, H.M.; Al-Sulaiman, F.A. Techno-economic evaluation of different types of solar collectors for water heating application in domestic sector of Saudi Arabia. In Proceedings of the 5th Renew Energy Congress (IREC), Hammamet, Tunisia, 25-27 March 2014.

104. Almasri, R.; Almarshoud, A. Feasibility of using evacuated tube solar water heaters in Saudi Arabia. Eur. J. Adv. Eng. Technol. 2017, 4, 232-241. 
105. Al-Sulaiman, F.; Almahmoud, H.; Abd-ur-rehman, H. Techno-economic evaluation of solar water heating applications at hospitals in Saudi Arabia. In Proceedings of the ISES Solar World Congress, Daegu, Korea, 8-12 November 2015.

106. Abd-ur-Rehman, H.M.; Al-Sulaiman, F.A. Optimum selection of solar water heating (SWH) systems based on their comparative techno-economic feasibility study for the domestic sector of Saudi Arabia. Renew. Sustain. Energy Rev. 2016, 62, 336-349. [CrossRef]

107. Al-Harbi, O.; Lehnert, K. Al-Khafji solar water desalination. In Proceedings of the KACST, IBM, the Saudi International Water Technology Conference, Riyadh, Saudi Arabia, 21-22 November 2011; 2011.

108. Household Electricity Price. Available online: www.globalpetrolprices.com (accessed on 1 August 2021).

109. Bakhshi-Jafarbadi, R.; Sadeh, J. Economic evaluation of grid-connected photovoltaic systems viability under a new dynamic feed-in tariff scheme: A case study in Iran. Renew. Energy 2018, 119, 354-364. [CrossRef]

110. Syria's Surprising Solar Boom: Sunlight Powers the Night in Rebel Idlib. Available online: https://www.nytimes.com/2021/05/ 15/world/middleeast/syria-solar-power-idlib.html (accessed on 1 August 2021).

111. Dehghan, M.; Pfeiffer, C.F. Modelling and control of collecting solar energy for heating houses in Norway. J. Sustain. Dev. Energy Water Environ. Syst. 2017, 5, 359-376. [CrossRef] 